\title{
D-Area Burning/Rubble Pits (431-D and 431-1D) Corrective Measures Study/Focused Feasibility Study
}

by

E. R. Palmer

Westinghouse Savannah River Company

Savannah River Site

Aiken, South Carolina 29808

J. T. Mason

DOE Contract No. DE-AC09-89SR18035

This paper was prepared in connection with work done under the above contract number with the U.S.

Department of Energy. By acceptance of this paper, the publisher and/or recipient acknowledges the U.S. Government's right to retain a nonexclusive, royalty-free license-in and to any copyright covering this paper; along with the right to reproduce and to authorize others to reproduce all or part of the copyrighted paper. 


\section{DISCLAIMER}

Portions of this document may be illegible electronic image products. Images are produced from the best available original document. 
APPROVAL PAGE

Revision 0

\section{D-AREA BURNING/RUBBLE PITS (431-D AND 431-1D) CORRECTIVE MEASURES STUDY/ FOCUSED FEASIBILITY STUDY (U) \\ $\&$}

\section{PROPOSED PLAN FOR THE D-AREA BURNING/RUBBLE PITS (431-D and 431-1D) (U)}

The attached document was completed under the direction of the Environmental Restoration Program Management Team at the Westinghouse Savannah River Company. We have reviewed the document, and to the best of our knowledge, it is true, accurate, and complete.

Date: $9 / 25 / 95 \quad$ Signature

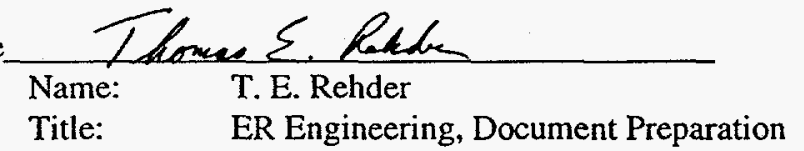

Date: $9 / 25 / 95$ Signature:

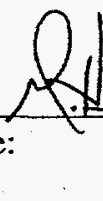

WSRC, ER Engineering

Date: $9 / 25 / 95$ Signature Name:

M. H. Smith

Project Team Leader

WSRC, Envirgnmental Restoration

Date: $9 / 25 / 95$ Signature

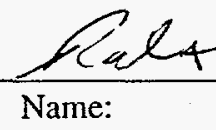

R. S. Aylward

Title:

Manager, Technology and Feasibility Study WSRC, Environmental Restoration

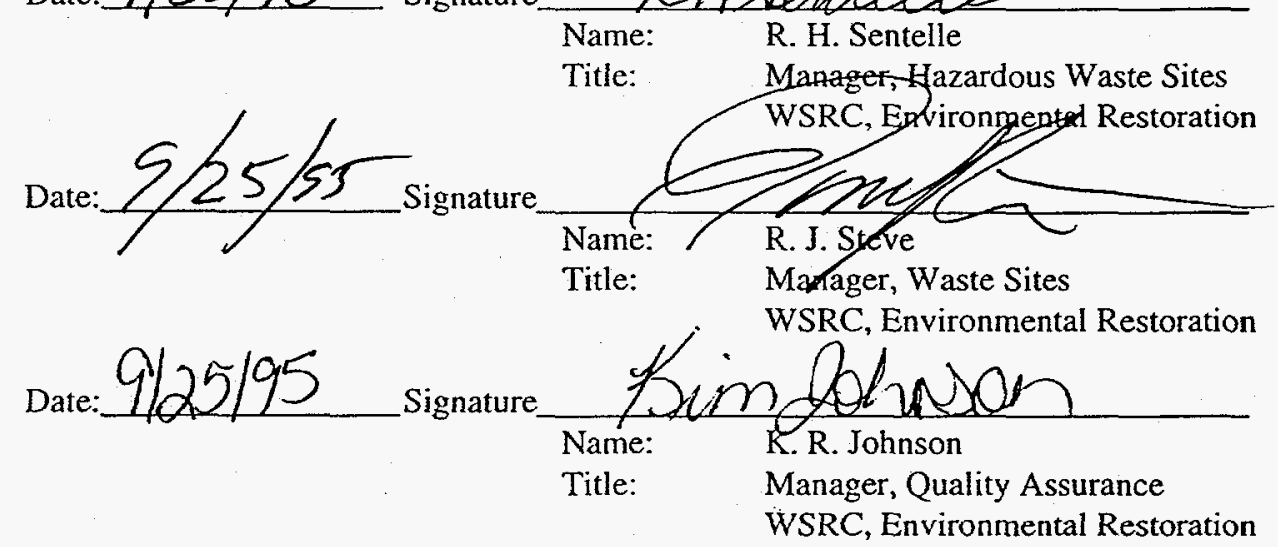

Date: $9 / 25 / 95$ Signature

WSRC, Environmental Restoration

\begin{tabular}{ll}
\hline Name: & K.S. Wherzbicki \\
Title: & Manager, Regulatory Compliance \\
& WSRC, Environmental Restoration
\end{tabular}




\section{CERTIFICATION PAGE}

\section{Revision 0}
D-AREA BURNING/RUBBLE PITS (431-D AND 431-1D) CORRECTIVE MEASURES STUDY/FOCUSED FEASIBILITY STUDY (U) $\&$ PROPOSED PLAN FOR THE D-AREA BURNING/RUBBLE PITS (431-D and 431-1D) (U)

"I certify under the penalty of law that this document and all attachments were prepared under my direction or supervision in accordance with a system designed to assure that qualified personnel properly gather and evaluate the information submitted. Based on my inquiry of the person or persons who manage the system, the information submitted is, to the best of my knowledge and belief, true, accurate, and complete. I am aware that there are significant penalties for submitting false information, including the possibility of fines and imprisonment for knowing violations."

Date:

Signature: Title:

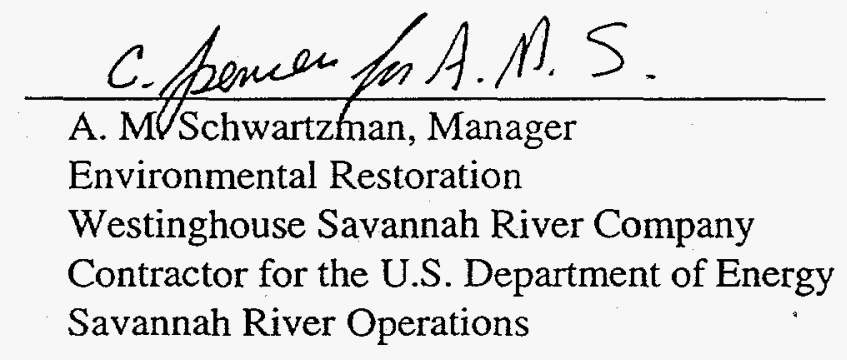

Date: Signature: Title:

C. V. Anderson, Director Environmental Restoration Division U.S. Department of Energy Savannah River Field Office 


\author{
WESTINGHOUSE SAVANNAH RIVER COMPANY \\ P.O. BOX 616 \\ AIKEN, SC 29802
}

DOCUMENT APPROVAL SUMMARY

\title{
D-AREA BURNING/RUBBLE PITS (431-D AND 431-1D) CORRECTIVE MEASURES STUDYI FOCUSED FEASIBILITY STUDY (U), WSRC-RP-95-904, Revision 0
}

\author{
PROPOSED PLAN FOR THE D-AREA BURNING/RUBBLE PITS (431-D and 431-1D) \\ WSRC-RP-95-905, Revision 0
}

September 29, 1995

\section{DOE FIELD OFFICE}

Savannah River Operations Office.

\section{DOCUMENT}

D-Area Burning/Rubble Pits (431-D and 431-1D) Corrective Measures Study/ Focused Feasibility Study (U), WSRC-RP-95-904, Revision 0, September 29, 1995.

Proposed Plan for the D-Area Burning/Rubble Pits (431-D and 431-1D) (U), WSRC-RP-95-905, Revision 0, September, 1995.

\section{REGULATORY SUMMARY}

The D-Area Burning/Rubble Pits (DBRP) (431-D and 431-1D) are subject to Comprehensive Environmental Response, Compensation, and Liability Act, 1980 (CERCLA) requirements. The D-Area Burning/Rubble Pits (431-D and 431-1D) Corrective Measures Study/Focused Feasibility Study and DArea Burning/Rubble Pits Proposed Plan were prepared to document the remedial alternative selection process for this Unit as required under CERCLA and to allow the public an opportunity to review and comment on the selection.

Five potential remedial alternatives were considered: No Action, Institutional Control, l' Soil Cover, 4' Soil Cover, and Thermal Desorption/Incineration. Institutional Control is recognized as the preferred alternative, providing adequate protection for human health and the environment with a satisfactory cost to benefit relationship.

The D-Area Burning/Rubble Pits (431-D and 431-1D) Corrective Measures Study/ Focused Feasibility Study (U) and Proposed Plan for the D-Area Burning/Rubble Pits (431-D and 431-1D) (U) are due to SCDHEC on September 29, 1995.

\section{BACKGROUND}

The DBRP were constructed in 1951, about the time construction began on the Savannah River Plant. Disposal of hazardous and radioactive wastes was not allowed in the DBRP. The pits received predominantly construction wastes such as scrap lumber, telephone poles and fence posts, paper and cardboard, plastic and rubber waste, solvents, degreasers, and lubricants, metal shavings and scraps, and concrete and asphalt rubble; combustible wastes were burned monthly until October 1973. After open burning was suspended, similar waste was placed in the pits, with the exception of solvents, degreasers, and lubricants. The DBRP were filled to capacity in 1983 and were covered with a layer of clean clay.

The DBRP were investigated by trenching in 1989, soil coring in late 1989 and May-December 1993, topographic mapping in June 1993, ground penetrating radar surveys, and soil gas surveys in July 1992. The groundwater monitoring at the DBRP began in 1983 when the first three wells (DBP 1-3) were installed. DBP 4 was completed in June 1984. DBP 5 was installed in June 1993. In June 1993, four 
new soil borings were made to 12 feet in each pit. Data from all these studies were considered in preparing the RFL/RI Report and the accompanying Baseline Risk Assessment (BRA) for the DBRP and formed the basis for the Corrective Measures Study/Feasibility Study and Proposed Plan.

Based on the field investigation, SRS believes that the nature and extent of contamination associated with the DBRP are adequately defined. In general, the contaminants placed in the DBRP are not found in the soil samples collected from deeper than 8-10 feet under the pits, indicating that the contaminants are not migrating toward the water table. For future on-unit workers and future resident scenarios, the carcinogenic risk determined in the BRA is $10 \mathrm{E}-6$ and the non carcinogenic hazard is less than 1.0.

\section{DOCUMENT APPROVAL}

The D-Area Burning/Rubble Pits Corrective Measures Study/Focused Feasibility Study (U) is a focused study which presents five alternative technologies. Consistent with the January 24, 1995 Citizens Advisory Board (CAB) recommendation on near term decision making for SRS CERCLA waste units, industrial land use criteria were utilized during the detailed analysis and one residential cleanup alternative (Thermal Desorption/Incineration) was retained. Costs for these alternatives range from about $\$ 10,000$ for No Action and Institutional Control to $\$ 1,200,000$ for Thermal Desorption/Incineration. Thermal Desorption/Incineration does not appear to yield a significant decrease in the carcinogenic risk or non carcinogenic hazard, both of which are already within EPA guidelines for No Action.

The only remaining risk is due to soil ingestion of PCB-1260. PCB-1260 was only found in boring 12 . Institutional Control conservatively offers sufficient protection for human health and the environment and is the option of choice for the closure of the DBRP. The purpose of the Proposed Plan is to describe the preferred alternative for addressing the DBRP and to provide an opportunity for public input into the remedial action selection process.

\section{ATTACHMENTS}

D-Area Burning/Rubble Pits (431-D and 431-1D) Corrective Measures Study/ Focused Feasibility Study (U), WSRC-RP-95-904, Revision 0, September 29, 1995.

Proposed Plan for the D-Area Burning/Rubble Pits (431-D and 431-1D) (U), WSRC-RP-95-905, Revision 0, September, 1995. 
United States Department of Energy

Savannah River Site

\section{D-Area Burning/Rubble Pits (431-D and 431-1D) Corrective Measures Study/Focused Feasibility Study (U)}

WSRC-RP-95-904

Revision 1

March 15, 1996

Prepared by:

Westinghouse Savannah River Company

Savannah River Site

Aiken, SC 29808

Prepared for the U. S. Department of Energy under Contract No. DE-AC09-89-SR18035

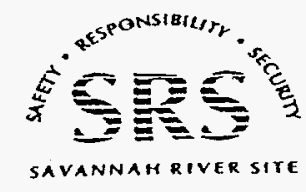




\section{CERTIFICATION}

\section{D-AREA BURNING/RUBBLE PITS (431-D and 431-1D) CORRECTIVE MEASURES STUDY/FOCUSED FEASIBILITY STUDY (U) Revision 1}

"I certify under penalty of law that this document and all attachments were prepared under my direction or supervision. in accordance with a system designed to ensure that qualified personnel properly gather and evaluate the information submitted. Based on my inquiry of the person or persons who manage the system, or those persons directly responsible for gathering the information, the information submitted is, to the best of my knowledge and belief, true, accurate, and complete. I am aware that there are significant penalties for submitting false information, including the possibility of fine and imprisonment of knowing violations."

Date:

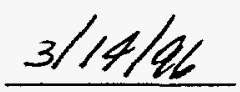

Date:

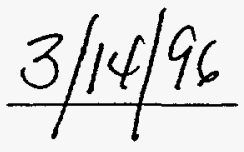

Signature:

Name: A. M. Schwartzmar

Title: Program Manager, Environmental Restoration Westinghouse Savannah River Company Contractor for the U.S. Department of Energy Savannah River Operations

Signature:

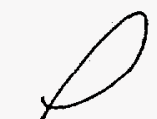

Name: C. V. Anderson

Title: Director, Environmental Restoration Division

U.S. Department of Energy

Savannah River Field Office 
This report was prepared by Westinghouse Savannah River Company (WSRC) for the United States Department of Energy under Contract No. DE-AC09-89-SR 18035 and is an account of work performed under that contract. Reference herein to any specific commercial product, process, or services by trademark, name, manufacturer, or otherwise does not necessarily constitute or imply endorsement, recommendation, or favoring of same by WSRC or by the United States Government or any agency thereof.

\author{
Printed in the United States of America \\ Prepared for \\ U. S. Department of Energy \\ by \\ Westinghouse Savannah River Company \\ Aiken, South Carolina
}



standards of control, and other substantive requirements, criteria, or limitations promulgated under federal environmental (RCRA, CWA, and SDWA) or state environmental or facility siting laws that (1) specifically address a hazardous substance, pollutant, contaminant, remedial action, location, or other circumstance found at a CERCLA site or (2) while not applicable to a specific hazardous substance, pollutant, contaminant, remedial action, location, or other circumstance found at a CERCLA site, address problems or situations sufficiently similar to those encountered at the CERCLA site that their use is well suited to the particular site. Only those state standards that are identified by the state in a timely manner and that are more stringent than federal requirements may be applicable or relevant and appropriate.

B(a)P
BCF
BRA
BRP
CAB
CERCLA
CMS/FFS
COC

COPCs

DBRP

$p, p^{\prime}-D D D$

p, $\mathrm{p}^{\prime}-\mathrm{DDE}$

$p, p^{\prime}-D D T$

DOE

EPA

FFS

HPCDD

NCP

OCDD

OSHA

PP

PCB

PCDD
Benzo(a)pyrene

Bioconcentration Factor

Baseline Risk Assessment

Burning/Rubble Pit

Citizens Advisory Board

Comprehensive Environmental Response, Compensation, and Liability Act, 1980

Corrective Measures Study/Focused Feasibility Study

Chemicals of concern are isolated from the list of COPCs by calculating carcinogenic risks and noncarcinogenic hazard indices. COPCs which contribute significantly to a pathway having a total carcinogenic risk of greater than $1 \times 10^{-4}$ are recognized as carcinogenic COCs. COPCs which contribute significantly to a pathway having a hazard quotient greater than 1.0 are considered noncarcinogenic COCs. A COC typically has a risk exceeding $1 \times 10^{-6}$ or a hazard quotient greater than 0.1 .

Chemicals of potential concern are site- and media-specific, man-made and naturally occurring inorganic and organic chemicals, pesticides, and radionuclides detected at a unit under investigation. The first step in isolating the COPCs is to eliminate all analytes with no detections and data with qualifiers which indicate uncertainty in chemical identification. Nonradionuclide inorganic analytes and naturally occurring radionuclides are recognized as COPCs if the maximum detected concentration is more than twice the mean background concentration in the same medium. Essential human nutrients (calcium, iron, magnesium, vanadium, copper, manganese, nickel, chromium, zinc, potassium, and sodium) are eliminated from consideration as COPCs if the levels are within the recommended daily allowances for the specific nutrient. Organic chemicals, both natural and anthropogenic, and pesticides are not screened against background, but are identified as COPCs if they are detected at the unit.

D-Area Burning/Rubble Pits

Dichlorodiphenyldichloroethane

Dichlorodiphenyldichloroethylene

Dichlorodiphenyltrichloroethane

United States Department of Energy

Environmental Protection Agency

Focused Feasibility Study

Heptachlorodibenzo-p-dioxin

National Oil and Hazardous Substances Pollution Contingency Plan, 1990

Octachlorodibenzo-p-dioxin isomers

Occupational Safety and Health Administration

Proposed Plan

Polychlorinated biphenyl

Polychlorinated dibenzo-p-dioxin 
D-Area Burning/Rubble Pits (431-D and 431-1D) Corrective Measures Study/Focused Feasibility Study (U) Savannah River Site

PCDF

Polychlorinated dibenzo furan

PRG

Preliminary Remediation Goals

PV

Present Value

RAO

Remedial Action Objectives

RCRA

Resource Conservation and Recovery Act, 1976

$\mathrm{RD} / \mathrm{RA}$

RFI

RFI/RI

$\mathrm{RI}$

Remedial Design/Remedial Action CERCLA work plan

RCRA Facility Investigation

RCRA Facility Investigation/ Remedial Investigation

ROD

Remedial Investigation

Record of Decision

SCDHEC

SRS

South Carolina Department of Health and Environmental Control

SVOC

Savannah River Site

TBC

Semi-Volatile Organic Compound

To Be Considered requirements (ARARs), federal and state criteria, advisories, and guidance that are not codified in the law.

TEF

Toxicity Equivalency Factor

TSCA

VOC

Toxic Substances Control Act, 1976

Volatile Organic Compound

WSRC

Westinghouse Savannah River Company 
D-Area Burning/Rubble Pits (431-D and 431-1D) Corrective Measures Study/Focused Feasibility Study (U) Savannah River Site

\section{Table of Contents}

Acronyms And Glossary. iv

Table of Contents.

List of Tables

List of Figures

1.0 INTRODUCTION

1.1 Site Description

1.2 Site History .

1.3 Nature and Extent of Contamination

1.3.1 Nature and Extent of Contamination in Source Area Soils (inside pits) ........................... 3

1.3.2 Nature and Extent of Contamination in Soil and Vadose Zone (outside pits) ...................5

1.3.3 Nature and Extent of Groundwater Contamination..................................................6

1.3.4 Nature and Extent of Surface Water and Sediment Contamination .................................6

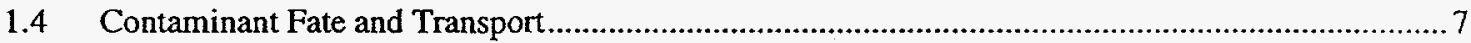

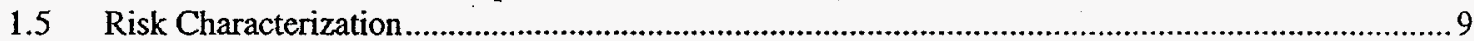

1.5.1 Current Land Use - Human Health ........................................................................... 9

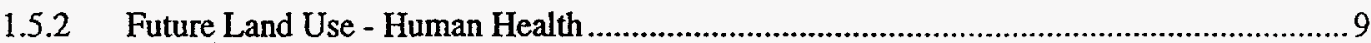

1.5.3 Radiological Risk - Human Health .................................................................. 10

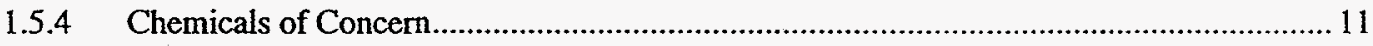

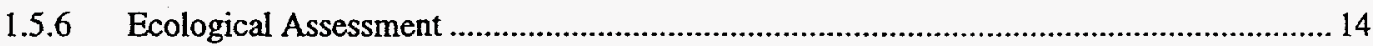

1.6 Critical Remedial Investigation Uncertainties........................................................... 14

1.6.1 Future Land Use - Human Health ............................................................... 14

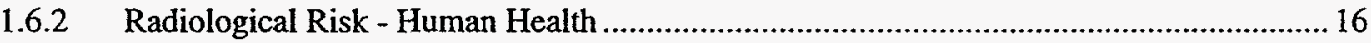

1.6.3 Measured Groundwater - Human Health .......................................................... 16

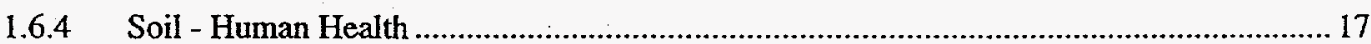

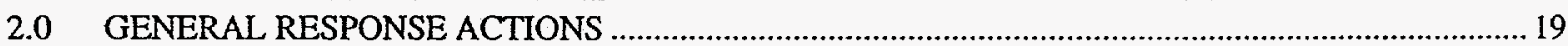

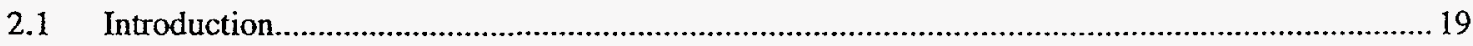

2.2 Remedial Action Objectives and Goals ..................................................................... 19

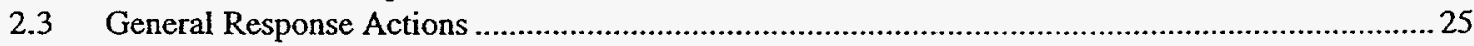

2.4 Identification of Technology Types and Process Options................................................26

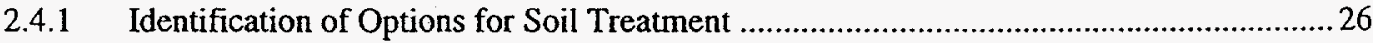

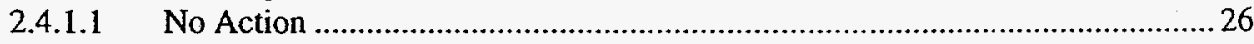

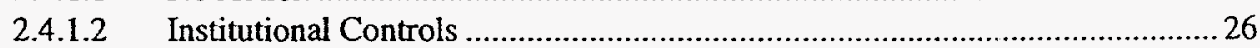

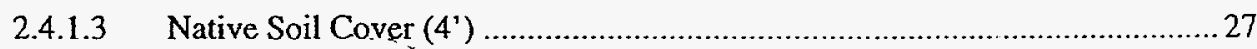

2.4.1.4 Remedial Treatment Technology ............................................................ 27

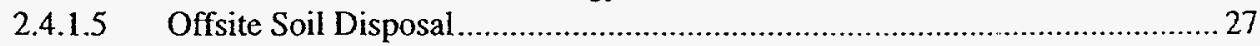

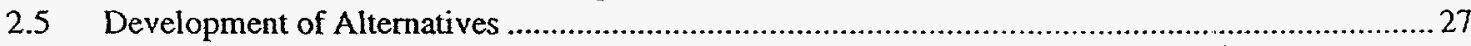

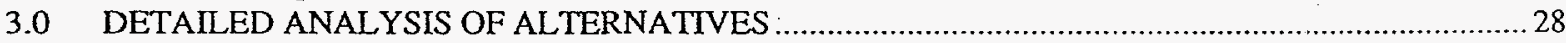

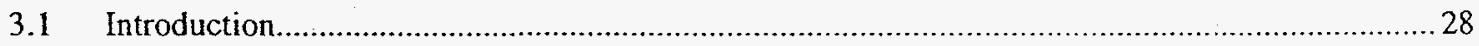

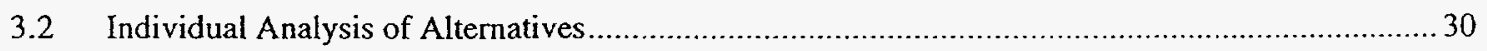

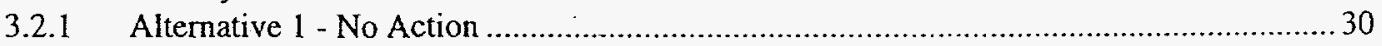

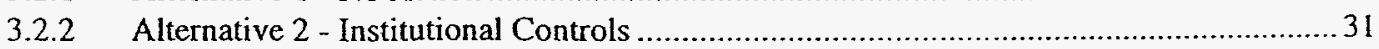

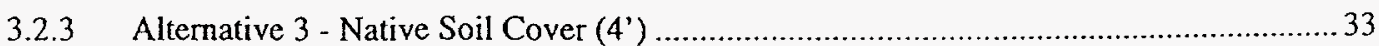

3.2.4 Alternative 4 - Thermal Desorption/Incineration................................................. 35

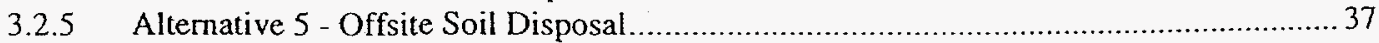

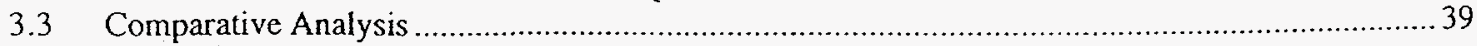

3.3.1 Summary of the Comparative Analysis of the Alternatives .................................42 
D-Area Burning/Rubble Pits (431-D and 431-1D) Corrective Measures Study/Focused Feasibility Study (U) Savannah River Site

March 15, 1996

WSRC-RP-95-904

Revision 1

March 15, 1996 Page vii of viii

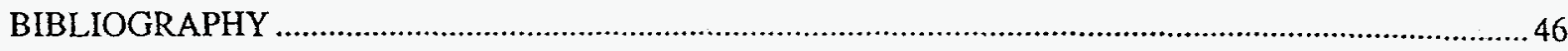

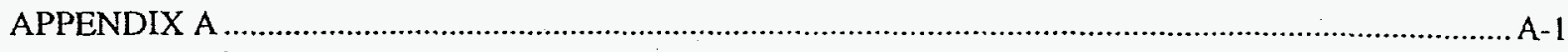

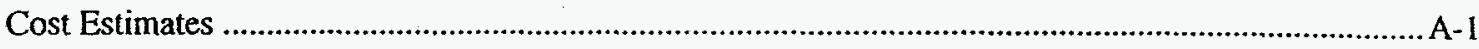

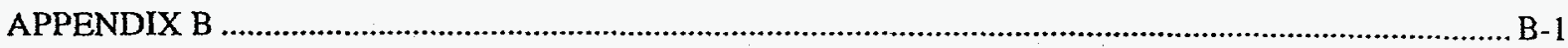

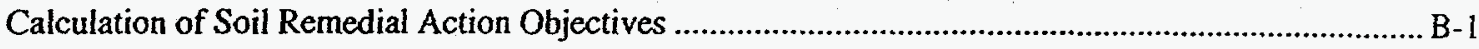

\section{List of Tables}

Table 1-1 List of DBRP Risk-Based Chemicals of Concern and the Media in Which They Exist (Residential Scenario).

Table 1-2

List of DBRP Chemicals of Concern Based on Absence of Toxicity Information and Media in Which they Exist

Table 1-3 Frequency of Detects of the Chemicals of Concern ...................................................... 18

Table 2-1 Estimated Human Health Risk Based RGOs ................................................................... 19

Table 2-2

Table 2-3 Groundwater Preliminary Remediation Goals (PRGs) ....................................................... 23

Table 2-4 Preliminary Remedial Action Objectives for DBRP Soils...........................................................25

Table 3-1

Table 3-2

Table A-1

Table A-2

Table A-3

Table A-4

Table A-5

Table B-1

Summary of the Alternatives Selected.

Summary of the Costs of the Alternatives......................................................................42

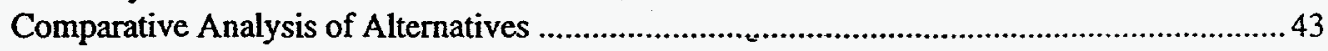

Present Value of Alternative 1 - No Action ...................................................................

Present Value of Alternative 2 - Institutional Controls ................................................... A-1

resent Value of Alternative 3 - Native Soil Cover (4') ....................................................

Present Value of Alternative 4 - Thermal Desorption/Incineration ......................................

Present Value of Alternative 5 - Offsite Soil Disposal ..................................................

Calculation of Soil Remedial Action Objectives .......................................................... B-1

Figure 1-1 Location of D-Area Burning/Rubble Pits at the Savannah River Site. 2

Figure 1-2 D-Area Buming/Rubble Pits 1993 Unit Assessment Sampling Locations with 1989 Sample Locations. . .4

Figure 1-3 Conceptual Risk Model of the Risks Posed by the DBRP 13 


\section{EXECUTIVE SUMMARY}

The D-Area Burning/Rubble Pits (DBRP) (431-D and 431-1D) at the Savannah River Site have been found to contain levels of contaminants that pose potential risks to human health. When soil contarninant levels were compared to background levels and the Applicable, or Relevant and Appropriate Requirements (ARARs), all of the soil levels were found to pose no concern except for PCB-1260 (polychlorinated biphenyl) (78\% of the associated risk), benzo(a)pyrene (B(a)P) (10\% of the associated risk), and octachlorodibenzo-p-dioxin (OCDD) ( $9 \%$ of the associated risk). The Baseline Risk Assessment (BRA) determined that there would be an increased cancer risk of approximately $1 \times 10^{-5}$ ( 1 in 100,000) for future residents through ingestion of surface soils. For an industrial land use scenario, this risk drops to $1 \times 10^{-6}$ ( 1 in 1,000,000) for future on-unit workers. The BRA determined that the contamination at the DBRP does not pose increased risk to the environment or to current onunit workers over existing background levels of contamination. The purpose of this repoit is to evaluate a focused set of alternatives which can be used to minimize the risk for these contaminated areas.

This waste unit does not pose a significant or complex site problem. Scoping meetings with the Environmental Protection Agency (EPA) and South Carolina Department of Health and Environmental Control (SCDHEC) were held to discuss contamination at the DBRP and the resulting risk. It was decided that a thorough consideration of a large number of treatment alternatives is unwarranted due to a lack of principal source material and the diffuse nature of the residual contamination present at the DBRP. A much larger suite of treatment alternatives has already been considered in the Corrective Measures Study (CMS)/Feasibility Study (FS) for the F-Area Burning/Rubble Pits (231-F, 231-1F and 231-2F) (FBRP) (WSRC, 1996). Similar wastes were managed in the FBRP and DBRP under similar conditions and practices; similar chemicals of concern have been recognized for both facilities. For these reasons, it was agreed that a focused feasibility study would be developed and that only the following five general response actions would be evaluated in this Corrective Measures Study/Focused Feasibility Study (CMS/FFS): 1) No Action, 2) Institutional Controls, 3) Soil Cover, 4) a remedial treatment technology, and 5) Soil Disposal. Five alternatives were formed from these five general response actions; these are: 1) No Action, 2) Institutional Controls, 3) Native Soil Cover (4'), 4) Thermal Desorption/Incineration, and 5) Offsite Soil Disposal. A summary of the costs for these alternatives is shown in the following table:

\begin{tabular}{|c|l|c|}
\hline Alt. No. & \multicolumn{1}{|c|}{ Alternative } & Costs \\
\hline \hline 1 & No Action & $\$ 0$ \\
\hline 2 & Institutional Controls & $\$ 10,346$ \\
\hline 3 & Native Soil Cover (4') & $\$ 235,620$ \\
\hline 4 & Thermal Desorption/Incineration & $\$ 1,502,000$ \\
\hline 5 & Offsite Soil Disposal & $\$ 1,084,000$ \\
\hline
\end{tabular}

The DBRP are located within an area that has been recommended for future industrial use by the SRS Citizens Advisory Board (CAB). There are no risks to future on-unit workers greater than $1 \times 10^{-6}$ for any contaminants attributable to the DBRP. 
The purpose of this report is to determine alternatives which may be used to remediate the D-Area Burning/Rubble Pits (DBRP). An objective of this process is to provide decision makers adequate information to compare altematives, select an appropriate remediation for the DBRP, and demonstrate the Comprehensive Environmental Response, Compensation, and Liability Act (CERCLA) requirements in the Record of Decision (ROD).

For the DBRP, the Baseline Risk Assessment (BRA) (WSRC, 1995a) and the Resource Conservation \& Recovery Act (RCRA) Facility Investigation/Remedial Investigation (RFIRI) Summary Report (WSRC 1995b) have been previously prepared and approved by the Environmental Protection Agency (EPA) and South Carolina Department of Health \& Environmental Control (SCDHEC). These documents serve as the basis for the decisions made in this Corrective Measures Study/Focused Feasibility Study (CMS/FFS).

During the Feasibility Study (FS) scoping meeting, it was decided that a focused feasibility study would be produced, rather than a complete CMS/FS, through an agreement reached by the EPA, SCDHEC, and the U. S. Department of Energy (DOE). A much larger suite of treatment alternatives has already been considered in the CMS/FS for the F-Area Burning/Rubble Pits (231-F, 231-1F and 231-2F) (FBRP) (WSRC, 1996). Similar wastes were managed in the FBRP and DBRP under similar conditions and practices; similar chemicals of concern have been recognized for both facilities. It was felt that a complex array of alternatives should not be discussed for this waste unit since the unit does not pose a significant or complex site problem. Thorough consideration of a large number of treatment alternatives for DBRP is unwarranted due to a lack of principal threat source material and the diffuse nature of the residual contamination present. The unit contains heterogeneous contamination at low concentrations over a relatively large area which would require treatment of large volumes of uncontaminated media in conjunction with limited volumes of media contaminated at relatively low concentrations. It was determined that only two remediation alternatives would be considered along with no action and two limited action alternatives.

The CMS/FS is conducted by following the sequence of events described in this paragraph. Applicable, or Relevant and Appropriate Requirements (ARARs) are identified for the individual Chemicals of Concern (COCs) and preliminary remediation goals, based on these ARARs, are developed. For each medium of interest, general response actions that may be taken to satisfy the remedial action goals for the DBRP are developed. Next, the volumes or areas of each medium are identified. These general response actions are evaluated with respect to the nine criteria established in the National Oil and Hazardous Substances Pollution Contingency Plan (NCP, 1990) and the selected general response actions are assembled into alternatives representing a range of treatment and containment combinations, as appropriate.

\subsection{Site Description}

The DBRP are a RCRA/CERCLA waste unit located within the Savannah River Site (SRS), approximately 2,600 feet west of D-Area and 1.6 miles west of State Highway 125. The Savannah River and associated swamps are located approximately 2,600 feet west of the pits (see Figure 1-1). The topography of the area is flat and the pits are at an elevation of 130 feet above mean sea level. The water table is approximately 10 feet below ground surface in the area of the BRP. Surface drainage is to the west-southwest toward a nearby unnamed ephemeral tributary of the Savannah River. The unit comprises two contiguous waste pits which are designated as 431-D and 431-1D and covers an area of 0.54 acres. Approximate dimensions of 431-D are 257 feet long by 46 feet wide by 10 feet deep, and the dimensions of $431-1 \mathrm{D}$ are 229 feet long by 36 feel 
D-Arca B urning/Rubble Pits (431-D and 431-1D) Corrective Mcasures Study/Focused Feasibility Study (U) Savannah River Site

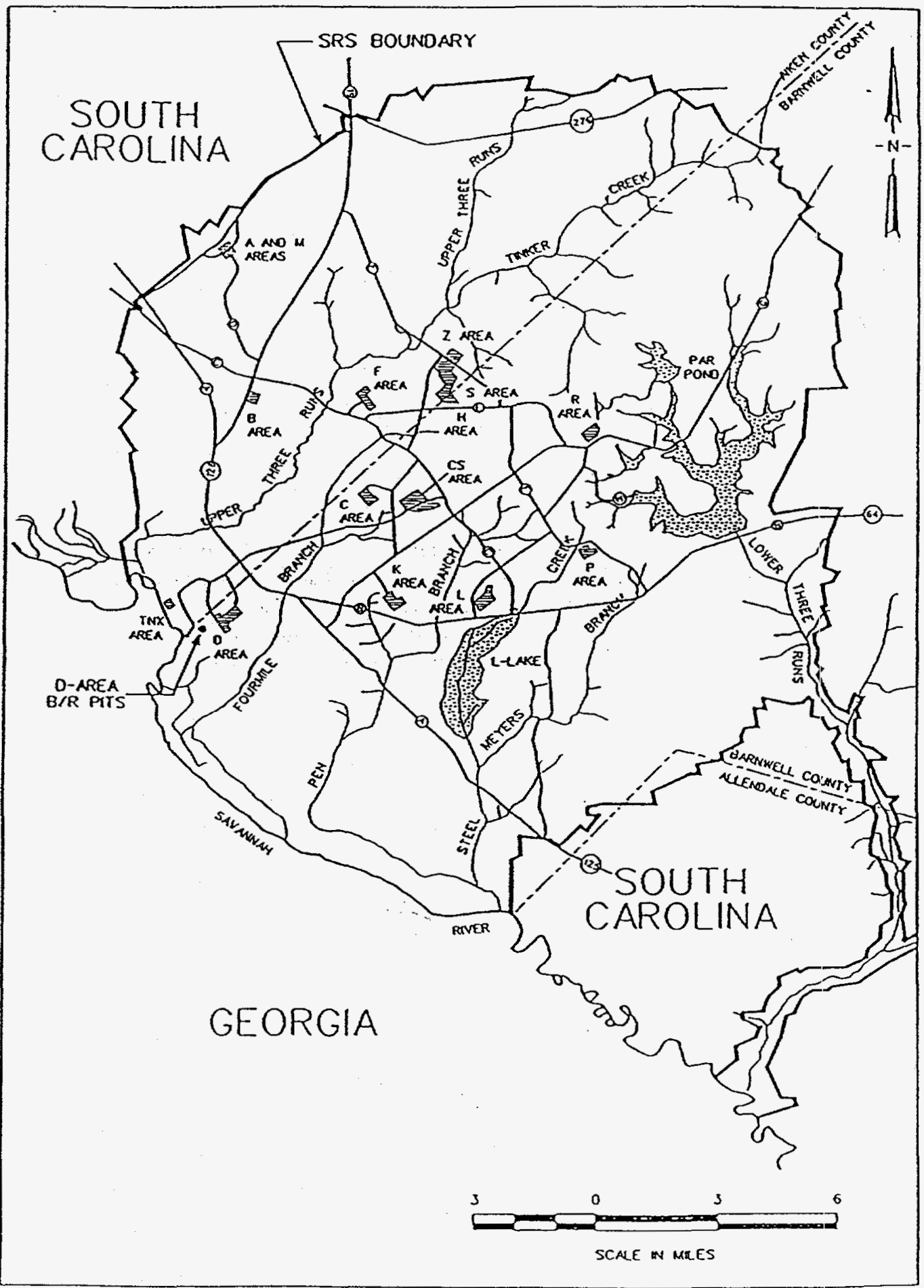


wide by 10 feet deep. The pits have been backfilled with clay soil and have vegetation established over the resulting surface. The area is essentially level, however, the pit cover is raised above the surrounding terrain to enhance drainage.

\section{$1.2 \quad$ Site History}

Between 1951 and 1973, burning/rubble pits were used at SRS to burn a variety of waste material. Waste was usually burned on a monthly basis. The chemical composition and volumes of the disposed waste are unknown, but waste materials burned included paper, plastics, wood, rubber, rags, cardboard, oil, degreasers, and spent organic solvents. No radioactive materials were allowed in the DBRP. BRPs at SRS were located in A, C, D, F, $\mathrm{K}, \mathrm{L}, \mathrm{P}$, and $\mathrm{R}$ Areas.

Burning of waste in the SRS pits was discontinued by October 1973. A layer of soil was then placed over the residue in each pit and they were subsequently used as rubble pits. Materials allowed in the rubble pits generally included concrete, bricks, tile, asphalt, plastic, metal, empty drums, wood products, and rubber. When the pits were filled to capacity or no longer needed (in 1983), a 1 to 3 foot layer of soil was placed over the contents and the surface was compacted and mounded. Vegetation has been established to reduce erosion.

\subsection{Nature and Extent of Contamination}

The volume of waste materials buried in the pits was estimated to be 74,100 cubic feet and 67,000 cubic feet in pits 431-D and 431-1D, respectively, based on the physical descriptions of the DBRP. Field geologic logs indicate that 2 feet of soil covers the buried debris. Several analyte groups, which include volatile organic compounds (VOCs), semi-volatile compounds (SVOCs), pesticides, polychlorinated biphenyls (PCBs), polychlorinated dibenzo-dioxins (PCDDs) and polychlorinated dibenzo-furans (PCDFs), metals and other inorganic compounds, and radionuclide parameters, were analyzed for in the soil, groundwater, surface water, and sediment. The analyses of the soil samples were divided into three groups:

- $\quad$ near-surface soils, 0 to $4 \mathrm{ft}$,

- debris interval soils, 4 to $10 \mathrm{ft}$, and

- underlying soils, greater than $10 \mathrm{ft}$

Additionally, soil samples were taken at eight locations within the pits, as well as, four locations outside the pits. Figure 1-2 identifies the soil boring locations as well as the locations of other media samples. This figure also shows the locations sampled in 1989 during the Phase I characterization of the DBRP. The following subsections provide a summary of the nature and extent of contamination in each medium.

\subsubsection{Nature and Extent of Contamination in Source Area Soils (inside pits)}

Analytical data for soil samples collected from within the DBRP indicate that SVOCs and metals are the most significant contaminants in source area soils. Contamination from SVOCs appears to be limited primarily to soils in the debris intervals $(4-10 \mathrm{ft})$ of both pits and, to a lesser extent, the soils underlying ( $10-12 \mathrm{ft})$ pit 431 1D. SVOCs common to these soils include bis(2-ethylhexyl)phthalate, butylbenzyl phthalate, phenanthrene, fluoranthene, benzo(b)fluoranthene, and benzo(a)anthracene. Low levels of SVOCs were detected in near surface soils and in soils underlying pit 431-D. 
D-Area Burning/Rubble Pits (431-D and 431-1D) Corrective Measures Study/Focused Feasibility Study (U) Savannah River Site

WSRC-RI'-95-904 March 15, 1996

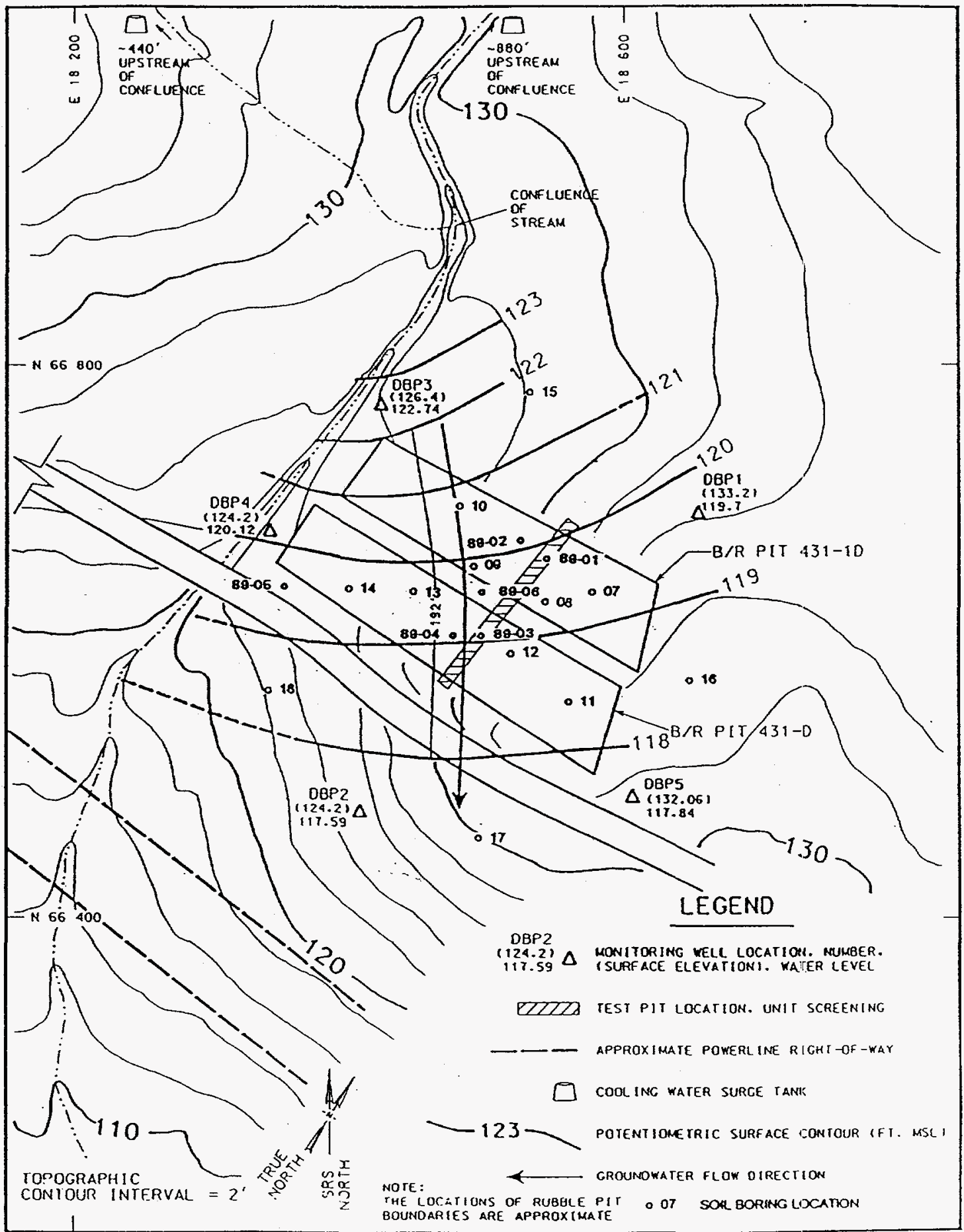


Six metals were detected in source area soils at concentrations greater than two times unit-specific background soil concentrations. Barium was detected in pits 431-1D (near surface soils) and 431-D (debris interval soils) at concentrations approximately three times higher than unit background soil concentrations. Copper was detected in pit 431-1D near surface soils and debris interval soils at concentrations approximately five times higher than unit background soil concentrations. Mercury was detected at concentrations in pit 431-1D near surface soils and underlying soils at approximately 6.5 and 2.5 times higher than unit background soil concentrations. Arsenic concentrations in pit 431-1D in the debris interval soils were reported at approximately 3.5 times higher than unit background soil concentrations. In pit 431-D, chromium was the only metal detected in near surface soils at concentrations above two times background. Selenium was detected at 2.25 times unit background concentrations in pit 431-D debris interval soils.

With the exception of acetone, analytical results indicate that source area soils are not significantly impacted by VOCs. Acetone was detected in the debris interval soils of both pits and the underlying soils of pit 431-D. Acetone is a common laboratory artifact. All other VOCs detected in debris interval soils were detected at relatively low levels.

Numerous pesticides were detected in pit soils, most of which were reported as estimated concentrations below the quantification limit. Maximum concentrations of the following pesticides exceeded the quantitation limit:

\begin{tabular}{ll}
\multicolumn{1}{c}{ 431-D } & \multicolumn{1}{c|}{ 431-1D } \\
chlordane & dieldrin \\
dieldrin & endosulfan \\
endosulfan II & endosulfan sulfate \\
endosulfan sulfate & p, p' DDE \\
endrin & \\
endrin ketone & \\
p, p' DDD & \\
p, p' DDE & \\
p, p'-DDT &
\end{tabular}

PCBs were detected in samples from both pits in relatively low concentrations. PCDD and PCDF compounds detected in all source area soil samples may be byproducts of various combustion processes and not a result of direct disposal. RCRA, 1976, Toxicity Characteristic Leaching Procedure (TCLP, September 1990) was developed using a subsurface fate and transport model for 40 common toxic constituents of potential concern. TCLP samples were collected in the pits. None of the TCLP metals, volatiles, semi-volatiles, or pesticides exceeded regulatory limits.

Pit soils do not appear to be significantly impacted by radionuclides. Non-volatile beta was detected in near surface soil samples from both pits at concentrations approximately 5 times higher than unit-specific background soil concentrations. Tritium was detected in pit 431-1D near surface soil and debris interval soil samples at concentrations approximately 2.6 times higher than unit specific background soil concentrations.

\subsubsection{Nature and Extent of Contamination in Soil and Vadose Zone (outside pits)}

Analytical data indicate that little or no significant impact to the soil media outside of the DBRP confines has occurred. Trace levels of VOCs were detected in samples downgradient of the pits, however, the presence of chlorinated VOCs in soil samples from outside the pits is not attributed to a release from the pits since no significant source of chlorinated VOCs remains in the pits. 
The only semi-volatile organic species detected in soil samples outside of the pits were bis(2ethylhexyl)phthalate and benzoic acid. The pits do not appear to be a significant source of polycyclic aromatic hydrocarbons (PAHs) to soil media outside the pits, since no PAH species were detected in soil samples downgradient of the pits.

Soil sampling results indicate that metals have not been released to soil media outside of the pits in significant levels. Manganese and selenium were the only two metals detected at concentrations above two times unitspecific background soil concentrations.

Nonvolatile beta and tritium were the only radionuclides detected in pit soils at concentrations in excess of two times unit-specific background concentrations. Unit background concentrations of gross alpha and nonvolatile beta are slightly elevated above levels characteristic of area-wide soils; however, background levels do not appear to have resulted from any release from the pits. Nonvolatile beta and tritium concentrations detected in soils downgradient and sidegradient of the pits were within two times unit-specific background concentrations, indicating that radionuclides have not migrated into the soil media from the pits.

\subsubsection{Nature and Extent of Groundwater Contamination}

Analytical data indicate that no significant release of hazardous substances to groundwater from the DBRP has occurred. There are 5 monitoring wells in the DBP well series: DBP-1,-2,-3 (installed in September 1983), DBP-4 (installed in June 1984), and DBP-5 (installed in June 1993). No VOCs were detected in sidegradient wells, and only trace levels of VOCs were detected in downgradient wells. The only constituent in the Unit Assessment samples (which included samples from three quarters in 1993) for which primary maximum contaminant levels (MCLs) were exceeded was gross alpha. The $\mathrm{MCL}$ for gross alpha is $15 \mathrm{pCi} / \mathrm{L}$, this level may have been slightly exceeded in the sample checked from well DBP-2 during December 1993, which was reported as $15 \pm 0.21 \mathrm{pCi} / \mathrm{L}$. The exceedence of gross alpha occurred only once in a single well that had previously contained no detectable gross alpha. SRS (DBP well series) groundwater data from 1984 through 1992 indicated that iron, lead, and manganese had the only MCL exceedences in downgradient or sidegradient wells in 8 years (32 quarters). Lead no longer has an MCL, but rather has a health advisory of $0.015 \mathrm{mg} / \mathrm{L}$ and a RCRA groundwater protection standard of $0.05 \mathrm{mg} / \mathrm{L}$.

Comparison of constituent levels in the four downgradient wells with levels in upgradient well DBP-3 indicate little or no constituent concentration increase in groundwater after flowing beneath the two BRPs. The only constituents which may show a significant increase are iron, manganese, sulfate, and possibly gross alpha and nonvolatile beta in one sample in DBP-2. Comparison of MCL exceedences of iron and manganese between the upgradient and downgradient wells indicates that these concentrations reflect naturally occurring conditions.

\subsubsection{Nature and Extent of Surface Water and Sediment Contamination}

Analytical data indicate no significant levels of VOCs in surface water or sediment. Chlorinated hydrocarbon species were not detected at concentrations above their respective quantitation limits in sediment samples.

PAHs, a component of the SVOC list, were detected in downstream sediment samples. Eviclence, based on the absence of PAHs in deeper soils within the pits, indicates that a release from the pits to surrounding soil or sediment probably has not occurred. The PAH constituents detected are common components of waste oil; the contamination at certain locations could possibly be due to surface water runoff from the gravel road that bisects those sediment sampling locations and the BRPs.

In accordance with EPA-Region IV guidance, data from downgradient sampling locations were evaluated against two times the average unit-specific background concentrations. Mean background values and two times 
background values for surface water metals and radionuclides were calculated and compared with downstream samples.

Only one downstream sample exceeded the mean background and two times background levels for manganese (a secondary drinking water contaminant) and tritium. The highest downstream value for tritium $(1,488 \mathrm{pCi} / \mathrm{L}$ ) was well below the $20,000 \mathrm{pCi} / \mathrm{L} \mathrm{MCL}$. Therefore, it is concluded that metal and radionuclides concentrations in surface water are within acceptable background ranges and that the surface water metal and radionuclide concentrations are not attributed to a release from the pits.

Downstream sediment values were compared with the respective values for two times the site-specific background for each metal, inorganic, and radionuclide parameter. Constituents exceeding two times background include the following:

$$
\begin{array}{ll}
\text { arsenic } & \text { lead } \\
\text { chromium } & \text { mercury } \\
\text { copper } & \text { selenium }
\end{array}
$$

Sediment constituents which significantly exceeded background are arsenic and mercury. Arsenic and mercury were detected in soils within the pits, so it is possible that a release from the pits of these two constituents has occurred.

Gross alpha and non-volatile beta concentrations exceeded unit-specific sediment background values in two sampling locations. Total alpha-emitting radium exceeded the unit-specific background concentration at one location. Two times the unit-specific tritium value was exceeded once in June 1993, but was not exceeded during the May 1994 sampling event, so there is no current evidence that tritium is present at unacceptable levels in the sediments.

\subsection{Contaminant Fate and Transport}

Review of the analytical data for environmental samples for the DBRP indicates that air, soils, groundwater, surface water, and sediments are media in which residual chemical migration potentially may occur. The fate and transport of residual chemicals is dependent on a variety of chemical and physical factors that are specific to both the residual chemicals and the environmental media. Additionally, climatic factors play an important role in determining the fate and transport of chemicals.

The primary source of residual chemicals at the DBRP is the soil within the pits. Soil within the DBRP can be generally classified as sand intermingled with varying amounts (0-35 percent) of clay or silty clay. Clay in the soil will enhance adsorption of the contaminants and limit their mobility from the unit. Since the pits have been covered with soil, percolation of surface water and transport of the residual chemicals to the saturated soil will be limited.

The water table in the vicinity of the BRPs does not appear to have risen into the pits during historical monitoring; however, the west side of the 431-D pit nearest the ephemeral stream is potentially susceptible to immersion during prolonged periods of unseasonably high rainfall. Low-levels of certain site-related chemicals were detected in groundwater at the DBRP, indicating that limited migration of contaminants from soils to groundwater has occurred. Groundwater flow in this area is generally to the south-southwest, toward a wetland area located south of the unit.

Surface water can transport chemicals to downstream sections of the Savannah River; however, it is not likely that significant levels of DBRP contaminants would migrate to the river because of the dilution that occurs along 
the route and within the Savannah River. Transport of VOCs and SVOCs from contaminated soil is possible, as well as suspension of soil particles to which contaminants become bound. Once in the air, contaminants can then be transported by air currents.

Physical and chemical properties of a contaminant affect the likelihood of that contaminant to remain unchanged or degrade via chemical or biological means. Generally, compounds with a high water solubility are more likely to remain dissolved in water, less likely to partition to soil, and more likely to biodegrade. The opposite effect is generally true for compounds with a low water solubility; they have a greater tendency to volatilize from water, have a greater tendency to partition to soil, and are less likely to biodegrade. Other fate processes that can be affected by water solubility include hydrolysis and oxidation. Compounds detected at the DBRP include primarily VOCs, SVOCs, pesticides, and metals. The SVOCs generally have lower solubilities and have a greater tendency to partition to soil as compared to the VOCs. Thus, the SVOCs generally tend to be adsorbed onto the soil particles rather than be dissolved in the groundwater. Pesticides and metals generally are readily adsorbed to soil particulates and thus are less mobile. Pesticides are susceptible to biodegradation, but generally at a very slow rate of degradation.

Groundwater transport modeling was conducted during the BRA to predict exposure point coricentrations at the source area. Very conservative assumptions in this modeling were made and include, but are not limited to, the following:

- Due to the location of groundwater just below the bottom of the pits, contaminants were allowed to partition directly between soil and groundwater (i.e., no unsaturated fate and transport modeling was employed).

- The Reasonable Maximum Exposure (RME) concentration is assumed to be the reasonable maximum concentration in soil. Groundwater comes into contact with soil and partitioning occurs.

- The concentration of the soil, used to determine the partitioning coefficient, is taken as the laboratory concentration. This is a conservative assumption for compounds which strongly favor the aqueous phase, since the concentrations reported by the laboratory are for material in both the aqueous and in the solid phase.

- The partitioning coefficient assumes linear, instantaneous, and reversible adsorption.

- A dilution factor of 0.56 was calculated based on a mixing depth of 2.3 meters at the downgradient edge of the pit. This dilution factor is conservative since a domestic well would probably require a longer well screen and would result in more dilution.

- The transport modeling equation assumes a constant inexhaustible input from the source area.

- Degradation was minimized by using the longest available half-life or assuming there was no degradation if a published half-life could not be found. 
The results of the transport modeling indicate that the following chemicals may exceed MCLs at the source area in the future:

benzene
benzo(a)anthracene
benzo(b)fluoranthene
benzo(k)fluoranthene
chrysene

benzene

benzo(b)fluoranthene

chrysene

\author{
dichloromethane \\ endrin \\ 1,2-dichloroethane \\ 1,1,2-trichloroethane
}

\subsection{Risk Characterization}

In the BRA, unit-specific data were used to identify contaminants of potential concern (COPC) to evaluate the risks to human receptors. Exposure scenarios were developed based on current and potential future activities. The receptors include a current on-unit visitor, a future industrial worker, and a residential family (See Figure 13). The current on-unit visitor is described as an employee of SRS who works at the DBRP for short periods on an infrequent basis, (i.e., a few hours per month performing sampling of maintenance activities). Chemical cancer risks and health hazards were estimated for each COPC for each of the receptors based on EPA Guidance. The threshold used in this risk assessment for determining unacceptable cancer risk for each COPC was $1 \times 10^{-6}$. Health hazards are expressed as a hazard index (HI); a hazard quotient (HQ), which is the sum of the hazard indices, of 1 or greater was the threshold for determining unacceptable health hazards. Therefore, for each exposure pathway, if an individual COPC exceeded a risk of $1 \times 10^{-6}$, or if the hazard quotient exceeded unity, the COPC or group of COPCs were considered risk-based COCs.

\subsection{Current Land Use - Human Health}

Under the current land use scenario, human health risks were characterized for the current on-unit visitor. All of the estimated nonradiological cancer risks were less than $1 \times 10^{-6}$, indicating that carcinogenic risk from the unit is insignificant. Media evaluated include soil inside the BRPs and soil outside the BRPs, associated airborne soil particulates, and surface water and sediment in the stream/wetland.

None of the HIs exceeds a value of one, indicating potential adverse noncarcinogenic health effects are unlikely. Noncarcinogenic hazard could not be calculated for exposure to particulates or VOCs because inhalation reference doses (RfDs) were not available for the COPCs.

All of the estimated radiological risks, except groundwater ingestion, were less than $1 \times 10^{-6}$. Radiological risks were estimated for three exposure pathways: ingestion of soil inside the BRPs, inhalation of particulates from soil inside the BRPs, and ingestion of sediment. Toxicity values, slope factors (SFs), were not available for the remaining potentially complete pathway: external radiation exposure from soil inside the BRPs. A slope factor is not available for external exposure to radiation from tritium, the only radioactive COPC in the shallow soil within the pits, because it does not emit gamma radiation. There were no radiological COPCs for soil outside the BRPs.

\subsubsection{Future Land Use - Human Health}

Several exposure pathways for the future on-unit resident had estimated nonradiological carcinogenic risks within the EPA's target risk range. Cancer risks for ingestion of soil from inside the BRPs for the $0-2 \mathrm{ft}$ and $0-4$ ft depths were within the $1 \times 10^{-6}$ to $1 \times 10^{-4}$ range. Estimated risks for dermal contact with soil and inhalation 
D-Area Burning/Rubble Pits (431-D and 431-1D) Corrective Measures Study/Focused Feasibility Study (U)

Savannah River Site

WSRC-RP-95-904

March 15, 1996

of soil particulates at both depths inside the BRPs were equal to $1 \times 10^{-6}$. Risks to the future resident from the accidental ingestion of surface water and sediment also were less than $1 \times 10^{-6}$.

The estimated risk for residential exposure to measured groundwater was $1 \times 10^{-3}$ for combined inhalation and ingestion exposure from residential use of groundwater. The principal contributor to this risk was arsenic, which was only detected once in 181 well quarters. The fourth quarter 1993 arsenic value for well $\mathrm{DBP}-5 \mathrm{was} 44 \mu \mathrm{g} / \mathrm{L}$ (the $\mathrm{MCL}$ is $50 \mu \mathrm{g} / \mathrm{L}$ ). The following quarter the value was less than the detection limits $(<2 \mu \mathrm{g} / \mathrm{L}$ ). This estimated risk may, therefore, be exaggerated.

For the modeled soil contribution to groundwater concentrations from soils inside the BRPs, the risks were $2 x$ $10^{-4}$ for dermal contact and $8 \times 10^{-4}$ for ingestion and inhalation. These risks were driven by cotachlorodibenzop-dioxin (OCDD) and heptachlorodibenzo-p-dioxin isomer (HpCDD) (dermal contact) and dieldrin (ingestion and inhalation).

Modeled cancer risks for ingestion of soil from inside the BRPs by future on-unit workers were equal to the EPA point of departure of $1 \times 10^{-6}$ for the $0-2 \mathrm{ft}$ depth interval. Estimated total risk for ingestion of groundwater was $3 \times 10^{-4}$ based on measured concentrations and $2 \times 10^{-4}$ based on modeled concentrations. Arsenic and dieldrin, respectively, were the principal contributors to these risks.

The HIs for the following pathways are all less than one, indicating adverse noncarcinogenic effects are unlikely:

- direct exposure of adult and child residents to soils inside and outside the BRPs

- direct exposure of child-only residents to soils inside and outside the BRPs

- exposure of a child to surface water and sediment

Noncarcinogenic hazard could not be calculated for inhalation of soil particulates and VOCs derived from soils because inhalation RfDs were not available for the COPCs.

The HIs for residential exposure to groundwater generally exceeded one. For measured exposure point concentrations, the HI for dermal contact (adult and child) was equal to one. The HI for combined ingestion and inhalation from residential exposure to groundwater was 50 (adult and child). Arsenic and manganese were responsible for the ingestion and inhalation hazards.

For the future on-unit worker, groundwater was the only exposure medium that had HIs greater than one. The HI for ingestion of groundwater based on measured concentrations was 6, with manganese and arsenic primarily responsible for this hazard. An HI of 10 was calculated for groundwater ingestion on the basis of modeled concentrations. Nitrobenzene was responsible for this hazard.

\subsubsection{Radiological Risk - Human Health}

Radiological risk levels for soil inside the BRPs at 0-4 $\mathrm{ft}$ depth and groundwater (measured and modeled) were within the EPA's target risk range for the residential scenario. The radiological risk level for external radiation exposure from soil at $0-4 \mathrm{ft}$ depth inside the BRPs was $1 \times 10^{-4}$, which is below the risk of $2 \times 10^{-4}$ that was calculated for the resident external radiation exposure to unit-specific background soils at $0-2 \mathrm{ft}$ depth. Both onunit and unit-background risks were driven by total radium.

Radiological risk for combined residential ingestion and inhalation of radionuclides in groundwater was $2 \times 10^{-5}$ based on measured groundwater concentrations. The primary contributor to risk was radium-226. The risk level 
based on modeled soil contribution to groundwater concentrations was $3 \times 10^{-5}$, and was driven by tritium and radium.

Risk levels for ingestion of leafy vegetables, tuberous vegetables, and fruits grown in soil inside the BRPs $(0-4 \mathrm{ft}$ depth) were all less than the EPA point of departure of $1 \times 10^{-6}$. Risk levels could not be calculated for ingestion of produce grown in soil inside the BRPs (0-2 ft depth) because a soil-to-plant uptake factor was not available for tritium, the only COPC. There were no radionuclide COPCs in soil outside the BRPs.

For the on-unit worker, radiological risk levels for three exposure pathways were within the EPA's target risk range of $1 \times 10^{-4}$ to $1 \times 10^{-6}$. Risk from external exposure to direct radiation from COPCs in soil at $0-4 \mathrm{ft}$ depth inside the BRPs was $9 \times 10^{-5}$. Radiological risk for combined ingestion and inhalation of radionuclides in groundwater was $6 \times 10^{-6}$ for measured concentrations and $1 \times 10^{-5}$ based on modeled concentrations.

\subsubsection{Chemicals of Concern}

Cancer risk levels at or above $1 \times 10^{-4}$ are generally considered significant by the EPA. Those COPCs determined to contribute significantly (chemical-specific risk of at least $1 \times 10^{-6}$ ) to a pathway having a total cancer risk of greater than $1 \times 10^{-4}$ were identified as carcinogenic COCs. An $\mathrm{HI}$ of one or greater has been defined as the level of concern for potential adverse noncarcinogenic health effects. Those COPCs determined to contribute significantly (HQ of at least 0.1 ) to a pathway having an $\mathrm{HI}$ greater than one were considered noncarcinogenic COCs.

None of the pathways for the current land use scenario had total cancer risk levels of $1 \times 10^{-4}$ or HIs greater than one. Therefore, no COCs were identified based on exposures under current land use conditions.

Under the future land use scenario, modeled groundwater was the only medium with exposure pathways that had cancer risks right at the EPA upper threshold of $1 \times 10^{-4}$ or HIs of one or greater. COCs were identified based on measured groundwater concentrations and based on groundwater concentrations modeled from soil concentrations. As discussed in Sections 1.3.3 and 1.5.2, these risks and hazards may also be exaggerated by a single anomalous occurrence. The majority of the COCs were identified on the basis of modeled groundwater concentrations.

A list of the risk-based COCs is provided in Table 1-1. This list considers the future resident scenario only. Table 1-2 lists the contaminants for which no toxicity information was available. 
D-Area Burning/Rubble Pits (431-D and 431-1D) Corrective Measures Study/Focused Feasibility Study (U) Savannah River Site

March 15, 1996

WSRC-RP-95-904

Revision 1

Page 12 of 46

Table 1-1 List of DBRP Risk-Based Chemicals of Concern and the Media in Which They Exist (Residential Scenario)

\begin{tabular}{|l|c|c|}
\hline Contaminant of Concern & $\begin{array}{c}\text { Soil (Modeled to } \\
\text { Groundwater }\end{array}$ & Groundwater \\
\hline 1,1,2-Trichloroethane & $\mathrm{x}$ & \\
\hline 1,2-Dichloroethane & $\mathrm{x}$ & \\
\hline 2,4 Dimethylphenol & $\mathrm{x}$ & \\
\hline 2- Methylnaphthalene & $\mathrm{x}$ & \\
\hline Acenaphthene & $\mathrm{x}$ & \\
\hline Acetone & & $\mathrm{x}$ \\
\hline Aluminum & $\mathrm{x}$ & $\mathrm{x}$ \\
\hline Arsenic & $\mathrm{x}$ & \\
\hline Benzene & $\mathrm{x}$ & \\
\hline Benzo(a) anthracene & $\mathrm{x}$ & \\
\hline Benzo(a)pyrene & $\mathrm{x}$ & \\
\hline Benzo(b)fluoranthene & $\mathrm{x}$ & \\
\hline Benzo(k)fluoranthene & $\mathrm{x}$ & \\
\hline Butylbenzyl phthalate & $\mathrm{x}$ & \\
\hline Dibenz(a,h) anthracene & $\mathrm{x}$ & \\
\hline Dibenzofuran & $\mathrm{x}$ & \\
\hline Dichloromethane (methylene chloride) & $\mathrm{x}$ & \\
\hline Dieldrin & $\mathrm{x}$ & \\
\hline Endrin & $\mathrm{x}$ & \\
\hline Fluoranthene & $\mathrm{x}$ & \\
\hline Fluoride & $\mathrm{x}$ & \\
\hline Hepta CDD & $\mathrm{x}$ & \\
\hline Hepta CDF & $\mathrm{x}$ & $\mathrm{x}$ \\
\hline Indeno(1,2,3-cd) pyrene & & \\
\hline Manganese & & \\
\hline Mercury & & \\
\hline Naphthalene & & \\
\hline Nitrate as N & & \\
\hline Nitrobenzene & & \\
\hline OCDD & & \\
\hline
\end{tabular}

Table 1-2 List of DBRP Chemicals of Concern Based on Absence of Toxicity Information and Media in Which they Exist

\begin{tabular}{|l|c|c|}
\hline Contaminant of Concern & $\begin{array}{c}\text { Soil } \\
\text { (Modeled to } \\
\text { Groundwater) }\end{array}$ & Groundwater \\
\hline \hline Endrin ketone & $x$ & \\
\hline delta-Benzene hexachloride & $x$ & \\
\hline Lead & $x$ & \\
\hline Lithium & $x$ & \\
\hline Phenanthrene & $x$ & \\
\hline Polychlorinated biphenyls (PCB) 1260 & $x$ & \\
\hline Chromium & $x$ & \\
\hline
\end{tabular}




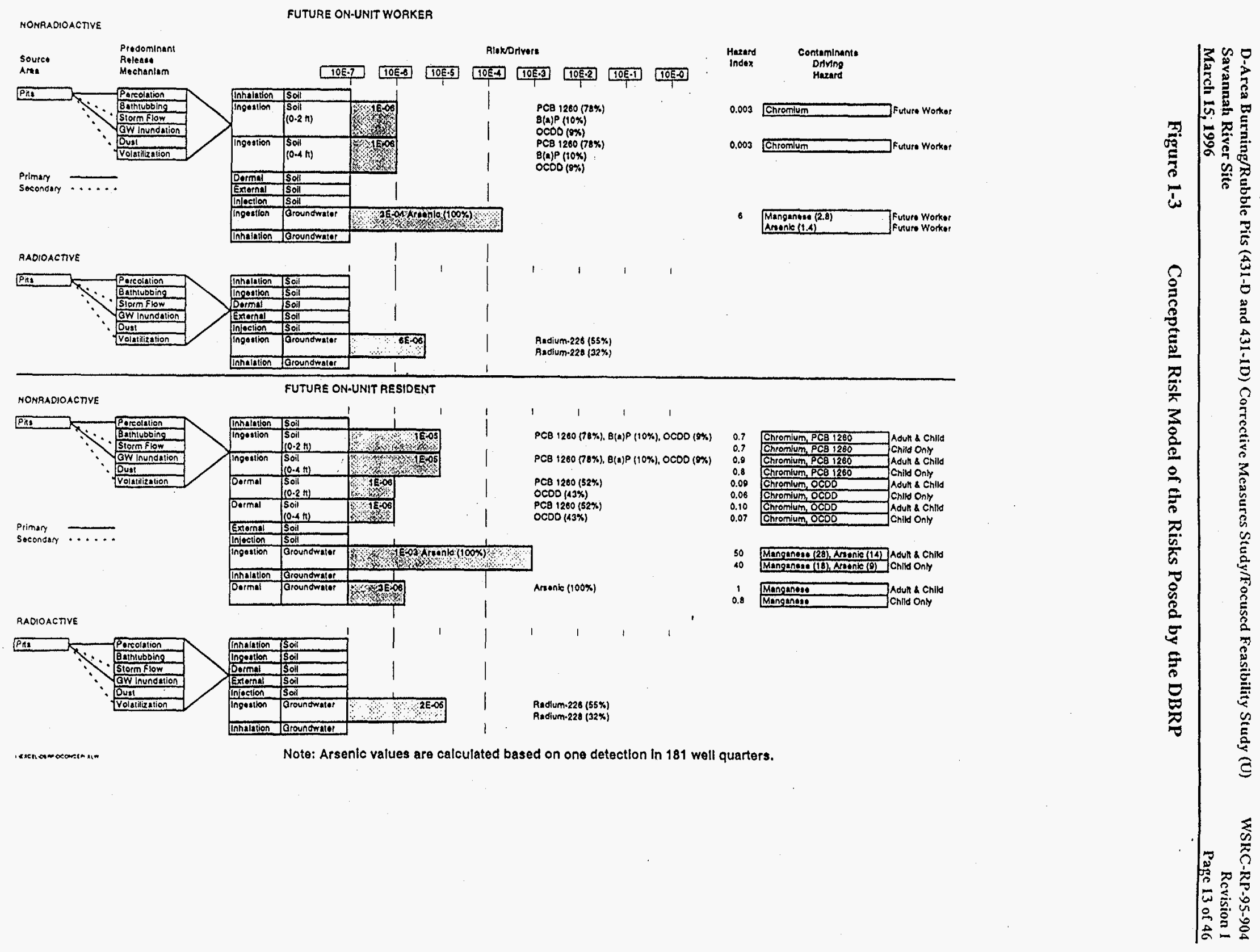




\subsubsection{Ecological Assessment}

The purpose of the ecological risk assessment component of the BRA was to evaluate the likelihood that adverse ecological effects are occurring or may occur as a result of exposure of ecological components to unit-related chemicals. The methodology consisted of four main elements: characterization of the unit, including the nature of the contamination which may exist and the ecological components which may be affected; exposure assessment, describing the magnitude and patterns of exposure; effects assessment, evaluating the potential toxicity of contaminants based on comparison of estimated intakes to toxicity benchmark intakes by calculation of quotients, as well as, on evaluation of bioaccumulation/biomagnification potential and other chemical characteristics; and risk characterization, integrating the results of the preceding elements in estimating risk, analyzing uncertainty, and interpreting the ecological significance of the assessment results.

Based on characterization of the environmental setting and identification of potential receptor organisms, a conceptual site model was developed to determine the complete exposure pathways through which receptors could be exposed to COPCs. Assessment endpoints were selected to represent ecological values to be protected with regard to exposure to unit-related chemicals, and measurement endpoints were selected which could be measured and related to the assessment endpoints.

The proximate assessment endpoints chosen were protection of small mammal populations at the unit, as represented by the native hispid cotton rat population and protection of populations of amphibians which may inhabit the small stream/wetland, as represented by southern chorus frogs. The ultimate assessment endpoint chosen was protection of the overall health and biodiversity of the community of species inhabiting the vicinity of the unit.

Toxicity benchmark intakes (terrestrial) or concentrations (aquatic) were derived for the measurement endpoints, and quotients were calculated to represent the ratio of estimated intakes or concentrations to the intakes or concentrations at which toxicity is likely to occur. The threshold for ecological effects is generally considered to be a quotient of one; greater quotients indicate greater likelihood of effects. Each COPC also was evaluated with regard to its bioaccumulation/biomagnification potential as represented by its bioconcentration factor (BCF).

The results of the risk estimation step of the risk characterization indicated that a few chemicals in the soil from the pits and surface water had quotients exceeding the threshold value of one, however, none actually posed more than minimal risk to the assessment endpoints. In addition, a variety of COPCs had BCFs which indicate that those chemicals might pose risk to assessment endpoints, however those COPCs generally were present in soil at levels much lower than their toxicity benchmärk levels.

Interpretation of the ecological significance of the unit-related contamination at the DBRP indicated that the likelihood of unit-related chemicals causing an ecologically significant decline in populations of native rats or other small mammals at the unit was very low; that the likelihood of significant effects on amphibiari populations due to surface water contaminants at the wetland was minimal; and that there was essentially no likelihood that significant impacts to the community of species in the vicinity of the unit will occur.

\subsection{Critical Remedial Investigation Uncertainties}

\subsection{Future Land Use - Human Health}

Estimated risk for residential exposure to measured groundwater was $1 \times 10^{-3}$ for combined inhalation and ingestion exposure from residential use of groundwater. The principal contributor to this risk was arsenic. However, arsenic was detected on only one (DBP-5) of seven samples, at a concentration of $43.6 \mathrm{ppb}$; the MCL 
for arsenic is $50 \mu \mathrm{g} / \mathrm{L}$. In the remaining six samples, arsenic was below the detection limit of 2 ppb. That same well which had an arsenic detection, was analyzed 11 days later and then again in the following two quarters with the arsenic results below the detection limit of $2 \mathrm{ppb}$. The risks from arsenic in measured groundwater reflect the concentration at one location in the pits (or may be a result of a laboratory artifact) and are not representative of the unit as a whole. WSRC, 1995a, recommends removing arsenic from the risk assessment, based on this low detection frequency, which would result in a re-calculated risk of below $1 \times 10^{-6}$.

For the modeled soil contribution to groundwater concentrations from soils inside the BRPs, the risks were $2 x$ $10^{-4}$ for dermal contact and $8 \times 10^{-4}$ for ingestion and inhalation. These risks were driven by octachlorodibenzop-dioxin (OCDD) and heptachlorodibenzo-p-dioxin isomer (HpCDD) (dermal contact) and dieldrin (ingestion and inhalation). Only two samples of dieldrin out of 45 were above the detection limit. The $95 \%$ upper confidence limit (UL95) concentrations in on-unit soil were used to calculate groundwater exposure point concentrations at the edge of the BRPs. Several conservative assumptions were used in this modeling, leading to very conservative estimates of future groundwater concentrations and thereby overestimating risk. RME soil concentrations were used as input values, assuming that these concentrations were applicable to the entire source area. Through instantaneous equilibrium, these RME concentrations were assumed to be transferred to groundwater (although this process occurs over time as a result of groundwater flow) and the concentrations were assumed to remain constant over time (i.e., no degradation or depletion). In addition, OCDD, HPCDD, and dieldrin have high $\mathrm{Kd}$ values. They readily adsorb to soil and would tend to remain localized at the source area rather than being dispersed throughout the groundwater. WSRC, 1995a, recommends removing dieldrin from the list of constituents of potential concern based on the low frequency of detections which results in a recalculated risk of $1 \times 10^{-4}$ for both pathways.

PCDDs and PCDFs contribute to risk from the ingestion/inhalation of and dermal contact with soils modeled to the groundwater for the resident and future workers. The risks presented in the BRA are determined with the assumption that 100 percent of the PCDD detected is chlorinated at the $2,3,7$, and 8 positions. This assumption was made because analytical results did not distinguished between different congeners and because the PCDD congeners chlorinated at the $2,3,7$, and 8 positions are considered a higher risk to human health.

Congeners chlorinated at the $2,3,7$, and 8 positions are selectively absorbed and/or retained in higher animals and therefore pose the greatest long-term human health effects (EPA, 1989b). However, studies indicate that in most environmental (soil, surface water, sediment, groundwater, and air) sampling, the amount of congeners not chlorinated at the $2,3,7$, and 8 positions vastly outweighs the amount of congeners chlorinated at the $2,3,7$, and 8 positions (EPA 1989b). In addition, recent EPA guidance (1994), Estimating Exposures to Dioxin-Like Compounds, Volume I: EPA/600/6-88-005Ca, indicates that all isomers of PCDD and PCDF have toxicity equivalency factors (TEFs) of 0 except for $2,3,7,8$-PCDD and $2,3,7,8$-PCDF. In this case, if the form of these two compounds is not the 2,3,7, and 8-halogenated congener, then the risks from exposure to a particular media have been greatly overestimated. If analytical results reflected PCDD and PCDF concentrations that were primarily congeners not chlorinated at the $2,3,7$ and 8 positions, risks from PCDDs and PCDFs presented in the BRA may be greatly reduced or even eliminated.

The HIs for residential exposure to groundwater generally exceeded one. For measured exposure point concentrations, the HI for dermal contact (adult and child) was equal to one. The HI for combined ingestion and inhalation from residential exposure to groundwater was 50 (adult and child). Arsenic and manganese were responsible for the ingestion and inhalation hazards. WSRC, 1995a, recommends removing arsenic from the risk assessment based on the low detection frequency and manganese due to the acceptable dietary intakes of this human nutrient. Removing these COCs would result in an HI of less than unity. The HI calculated on the basis of modeled groundwater exposure point concentrations was 10 (adult and child). The COPCs responsible were nitrobenzene, $\mathrm{OCDD}$, and $\mathrm{HPCDD}$. For ingestion and inhalation of modeled groundwater concentrations based on soil contribution from the BRPs, the calculated HI was 100 (adult and child). The COPCs driving these hazards were nitrobenzene and acetone. WSRC, 1995a, recommends removing nitrobenzene from the 
hazard calculations based on the low frequency of detection in the groundwater, which would result in an HI of 20.

For the future on-unit worker, groundwater was the only exposure medium that had HIs greater than one. The $\mathrm{HI}$ for ingestion of groundwater based on measured concentrations was 6 , with manganese and arsenic primarily responsible for this hazard. An $\mathrm{HI}$ of 10 was calculated for groundwater ingestion on the basis of modeled concentrations. Nitrobenzene was responsible for this hazard, therefore the removal of this $\mathrm{COC}$ would reduce the HI to less than unity.

\subsubsection{Radiological Risk - Human Health}

Both on-unit and unit-background risk were driven by total radium, a naturally occurring radionuclide which would have been eliminated as a COPC in the 0-4 $\mathrm{ft}$ soils inside the BRPs if it had been compared to unit specific background. (It was not compared because unit-specific background data were available only for the 0$2 \mathrm{ft}$ depth.) The risks from soils at 0-4 ft depth inside the DBRP may derive from background levels of total radium, in which case risk was overestimated for the DBRP.

Radiological risk for combined residential ingestion and inhalation of radionuclides in groundwater was $2 \times 10^{-5}$ based on measured groundwater concentrations. The primary contributor to risk was radium-226. The risk level based on modeled soil contribution to groundwater concentrations was $3 \times 10^{-5}$, and was driven by tritium and radium. This risk may be overestimated because of the conservative assumptions used in the modeling of soil contaminants partitioning to groundwater.

\subsubsection{Measured Groundwater - Human Health}

As calculated in the Baseline Risk Assessment (BRA) for the DBRP, six constituents were identified as COCs in the measured groundwater. The identified COCs include: aluminum, arsenic, fluoride, manganese, mercury, and nitrate plus nitrite as nitrogen. The analysis data, Applicable Relevant and Appropriate Requirements (ARARs), and toxicity information of these contaminants were reviewed as part of the CMS/FS process to confirm the need to remediate these constituents from the groundwater. Findings from this review indicate that the levels of these constituents do not warrant remediation and should be dropped from the list of COCs. A discussion of each constituent is provided below:

\section{Aluminum}

Aluminum was identified as a COC based on a Hazard Quotient (HQ) of greater than unity for the ingestion of groundwater for the future resident scenario. Although the concentrations in the downgradient wells were greater than the concentrations in the upgradient well (DBP-3), questions arose regarding the toxicity of aluminum. The only ARARs that were identified for aluminum are the Federal Ambient Water Quality Criteria for the Protection of Freshwater Organisms. No analyses for aluminum were available for the surface water or sediment for which this ARAR would apply. No human health toxicity information is provided in IRIS or HEAST for aluminum. The BRA uses an Rfd of $0.1 \mathrm{mg} / \mathrm{kg} / \mathrm{d}$ ( $\mathrm{kg}$ is baby's weight) with the source given as Superfund Health Risk Technical Support Center - Environmental Criteria and Assessment Office (SHRTSCECAO, EPA, 1992). The use of this RfD results in a maximum HQ of 7.18. In the development of the Remedial Alternative Objectives (RAOs) process, EPA Region III risk-based screening criteria (EPA, 1994b) were reviewed. Within the tables of this EPA document, an oral RfD for aluminum was cited as $2.9 \mathrm{mg} / \mathrm{kg} / \mathrm{d}$ (the source of this value was cited as "other EPA documents"). Using an oral RfD of 2.9 would result in a HQ of 0.25 for the same pathway in the BRA. 
Arsenic

Arsenic was identified as a carcinogenic and noncarcinogenic $\mathrm{COC}$ for the ingestion (and inhalation pathway while showering) pathway for the future on-unit resident using the measured groundwater concentrations. The groundwater data for arsenic shows only 1 value above the detection limit in 9 samples. This detection of arsenic occurred in DBP-5, which is a relatively new well. This well was sampled 11 days after the first detection of arsenic occurred and the arsenic value was found at less than the detection limit $(2 \mu \mathrm{g} / \mathrm{L}$, see Sections 1.5.2 and 1.6.1). First quarter 1994 well data show arsenic at less than detection as well.

\section{Fluoride}

The HQ for fluoride is less than unity. The maximum measured groundwater concentration is less than $10 \%$ of the MCL for fluoride. The estimated range of safe and adequate intakes of fluoride for adults is 1.5 to 4.0 $\mathrm{mg} /$ day (National Research Council, 1989). Using the assumption that the future on-unit resident drinks 2 liters per day, the daily intake of fluoride based on the maximum measured concentration of $396 \mu \mathrm{g} / \mathrm{L}$ would be below the lower end of this range $(0.8 \mathrm{mg} /$ day $)$.

\section{Manganese}

The HQ for manganese was calculated to be 26.3. The estimated_range of safe and adequate intakes of manganese for adults is 2.0 to $5.0 \mathrm{mg} /$ day (National Research Council, 1989). Using the assumption that the future on-unit resident drinks 2 liters of groundwater per day, the daily intake of manganese based on the maximum measured concentration of $1440 \mu \mathrm{g} / \mathrm{L}$ would be within this range $(2.9 \mathrm{mg} / \mathrm{day})$.

\section{Mercury}

The HQ for mercury is below unity. The maximum measured groundwater concentration of mercury is less than half of its MCL.

\section{Nitrate/Nitrite}

Nitrate plus nitrite as nitrogen resulted in a calculated HQ of 4.1. Nitrate/nitrite, however, was found at high levels in the background well (DBP-3). Based on the methodology described in Section 3.1.1 of the BRA, a contaminant was dropped from consideration if the maximum detected concentration was less than twice the mean background concentration. Nitrate/Nitrite should have been dropped from consideration with the application of this methodology (maximum detected concentration - $5900 \mu \mathrm{g} / \mathrm{L}$; mean background concentration $-3460 \mu \mathrm{g} / \mathrm{L}$ ). Additionally, the maximum nitrate/nitrite concentration is less than its $\mathrm{MCL}$ value $(10,000 \mu \mathrm{g} / \mathrm{L})$.

\subsubsection{Soil - Human Health}

The only constituents detected in the soil which were identified as COCs in the BRA were those that were modeled from the soil to the groundwater. The model used to predict concentrations in the groundwater is based upon very conservative assumptions. The model does not include a time element, therefore, the breakthrough time of the contaminant to reach the groundwater could be considered as instantaneous. The waste was placed in the pits over 20 years ago, yet the groundwater investigation (as part of the RL/RFI), did not find the soil COCs in the groundwater at or near the modeled concentrations.

Based on the frequency of detections (see Table 1-3), the following contaminants were deleted from the soil COC list for the DBRP CMS/FS: 2,4-dimethylphenol, benzene, dieldrin, endrin, HPCDF, and nitrobenzene. 
D-Area Burning/Rubble Pits (431-D and 431-1D) Corrective Measures Study/Focused Feasibility Study (U) Savannah River Site

WSRC-RP-95-904

March 15, 1996

These contaminants are shaded in the table below. Acetone and dichloromethane are common $\|$ ab contaminants. As indicated in the Data Summary Report, acetone was found in the associated blanks of 8 out of 20 detections. Risk and hazard values were calculated using the maximum value of $5800 \mu \mathrm{g} / \mathrm{kg}$. This value was demarked in the data summary report as having a detection in the associated blank. The HQ calculated for acetone may not be representative of the contamination in the soil. Benzene was only detected twice in the soil within the pits and was not detected in the groundwater. The highest uptake reported from the pit soil was estimated to be 5.21 $\mu \mathrm{g} / \mathrm{kg}$ from sample 1305.

Table 1-3 Frequency of Detects of the Chemicals of Concern

\begin{tabular}{|c|c|}
\hline Contaminant of Concern & Frequency of detects \\
\hline 1,1,2-Trichloroethane & $10 / 55$ \\
\hline 1,2-Dichloroethane & $13 / 55$ \\
\hline 2,41 Iinethy 1 phenol & 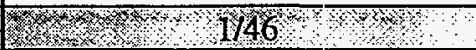 \\
\hline 2- Methylnaphthalene & $6 / 46$ \\
\hline Acenaphthene & $8 / 46$ \\
\hline Acetone & $18 / 24$ \\
\hline Arsenic & $39 / 56$ \\
\hline Benzene & 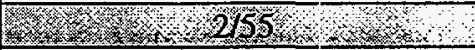 \\
\hline Benzo(a) anthracene & $11 / 46$ \\
\hline Benzo(a)pyrene & $8 / 46$ \\
\hline Benzo(b)fluoranthene & $10 / 46$ \\
\hline Benzo(k)fluoranthene & $8 / 46$ \\
\hline Butylbenzyl phthalate & $8 / 46$ \\
\hline Dibenz $(\mathrm{a}, \mathrm{h})$ anthracene & $3 / 46$ \\
\hline Dibenzofuran & $7 / 46$ \\
\hline Dichloromethane (methylene chloride) & $4 / 22$ \\
\hline $\begin{array}{l}\text { Bidonin } \\
\text { Endin }\end{array}$ & 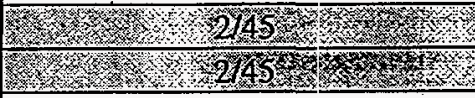 \\
\hline Fluoranthene & $12 / 46$ \\
\hline $\mathrm{HCDD}$ & $10 / 43^{-\infty}$ \\
\hline 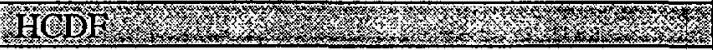 & $2 x-143 \times 3$ \\
\hline Indeno $(1,2,3$-cd)pyrene & $7 / 46$ \\
\hline Naphthalene & $7 / 46$ \\
\hline Nitobenzene & 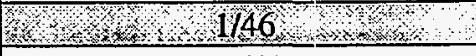 \\
\hline OCDD & $41 / 43$ \\
\hline
\end{tabular}




\subsection{GENERAL RESPONSE ACTIONS}

The primary objective of this section of the CMS/FFS is to evaluate the four selected general response actions, determine the remedial goal objectives (RGOs), select several alternatives using the general response actions, and determine how well each alternative meets the RGOs.

\section{$2.1 \quad$ Introduction}

The five general response actions that were agreed upon with the EPA and SCDHEC were 1) no action, 2) institutional controls, 3) soil cover, 4) a remedial treatment technology, and 5) soil disposal. The identified remedial technology must be effective in the remediation of polychlorinated biphenyls (PCBs), B(a)P, and OCDD in the soil and must meet the remedial action objectives. Thermal desorption/incineration was selected as the remedial technology of choice because it is known to be effective in separating these contaminants from soil and this process permanently destroys the contaminants in the incineration process. Offsite soil disposal was added as an altemative method which would also fully remediate the area.

\subsection{Remedial Action Objectives and Goals}

In the development of the remedial action objectives, the preliminary remediation goals that were identified in the BRA were reviewed along with the data, assumptions, parameters, and calculations used to develop them. For the DBRP, the BRA identified risk-based COCs for exposure pathways involving the ingestion of soil from the $0-2 \mathrm{ft}$ and the 0-4 ft layers of soil for the future on-unit resident scenario. (For current use conditions, no risk-based COCs were identified.) Contaminants in all other media resulted in only negligible risks and hazards. The risk-based COCs were based on concentrations in the groundwater monitoring wells during the Remedial Investigation/RCRA Facility Investigation (RI/RFI) and modeled groundwater concentrations from the soil contaminants.

Table 2-1

Estimated Human Health Risk Based RGOs

\begin{tabular}{|c|c|c|c|c|c|c|}
\hline \multirow[t]{2}{*}{ Contaminant } & \multicolumn{3}{|c|}{$\begin{array}{c}\text { Carcinogenic Risk } \\
(\mu \mathrm{g} / \mathrm{L})\end{array}$} & \multicolumn{3}{|c|}{$\begin{array}{c}\text { Hazard Index } \\
(\mu g / L)\end{array}$} \\
\hline & $1 \times 10^{-6}$ & $1 \times 10^{-5}$ & $1 \times 10^{-4}$ & 0.1 & 1 & 10 \\
\hline \multicolumn{7}{|c|}{ 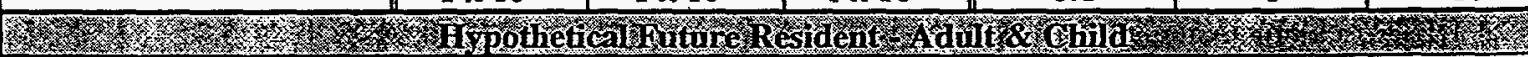 } \\
\hline \multicolumn{7}{|c|}{ Groundwater - Measured Concentrations } \\
\hline Arsenic & $3.8 \times 10^{-2}$ & 0.38 & 3.8 & 0.33 & 3.3 & 33 \\
\hline Aluminum & ND & $\mathrm{ND}$ & $\widehat{\mathrm{ND}}$ & 109 & 1,090 & 10,900 \\
\hline Fluoride & $\mathrm{ND}$ & ND & $\mathrm{ND}$ & 66 & 660 & 6,600 \\
\hline Manganese & ND & ND & ND & 5.5 & 55 & 550 \\
\hline Mercury & ND & ND & $\mathrm{ND}$ & 0.33 & 3.3 & 33 \\
\hline Nitrate & ND & $\mathrm{ND}$ & $\mathrm{ND}$ & 109 & 1,090 & 10,900 \\
\hline
\end{tabular}


D-Area Burning/Rubble Pits (431-D and 431-1D) Corrective Measures Study/Focused Feasibility Study (U)

Savannah River Site

WSRC-RP-95-904

March 15, 1996

Revision 1

Page 20 of 46

\begin{tabular}{|c|c|c|c|c|c|c|}
\hline \multirow[t]{2}{*}{ Contaminant } & \multicolumn{3}{|c|}{$\begin{array}{c}\text { Carcinogenic Risk } \\
(\mu \mathrm{g} / \mathrm{L})\end{array}$} & \multicolumn{3}{|c|}{$\begin{array}{c}\text { Hazard Index } \\
(\mu \mathrm{g} / \mathrm{L})\end{array}$} \\
\hline & $1 \times 10^{-6}$ & $1 \times 10^{-5}$ & $1 \times 10^{-4}$ & 0.1 & 1 & 10 \\
\hline \multicolumn{7}{|c|}{ (1) } \\
\hline \multicolumn{7}{|c|}{ Groundwater - Modeled Concentrations } \\
\hline 1,1,2-Trichloroethane & 0.58 & 5.8 & 58 & 4.3 & 43 & 430 \\
\hline 1,2-Dichloroethane & 0.37 & 3.7 & 37 & ND & ND & ND \\
\hline 2-Methylnapthalene & ND & ND & ND & 27 & 270 & 2,700 \\
\hline Acenaphthene & ND & ND & $\mathrm{ND}$ & 41 & 410 & 4,100 \\
\hline Acetone & ND & $\mathrm{ND}$ & ND & 109 & 1,090 & 10,900 \\
\hline Benzo(a)anthracene & $9.2 \times 10^{-3}$ & $9.2 \times 10^{-2}$ & 0.92 & $\mathrm{ND}$ & $\mathrm{ND}$ & $\mathrm{ND}$ \\
\hline Benzo(a)pyrene & $9.2 \times 10^{-3}$ & $9.2 \times 10^{-2}$ & 0.92 & ND & ND & $\mathrm{ND}$ \\
\hline Benzo(b)fluoranthene & $9.2 \times 10^{-3}$ & $9.2 \times 10^{-2}$ & 0.92 & ND & $\mathrm{ND}$ & ND \\
\hline Benzo(k)fluoranthene & $9.2 \times 10^{-3}$ & $9.2 \times 10^{-2}$ & 0.92 & $\mathrm{ND}$ & ND & ND \\
\hline Butylbenzylphthalate & ND & ND & $\mathrm{ND}$ & 220 & 2,200 & 20,200 \\
\hline Dibenz(a,h)anthracene & $9.2 \times 10^{-3}$ & $9.2 \times 10^{-2}$ & 0.92 & $\mathrm{ND}$ & $\mathrm{ND}$ & $\mathrm{ND}$ \\
\hline Dibenzofuran & $\mathrm{ND}$ & $\mathrm{ND}$ & ND & 4.0 & 40 & 400 \\
\hline Dichloromethane & 15 & 150 & 1,500 & $\mathrm{ND}$ & ND & $\mathrm{ND}$ \\
\hline Fluoranthene & $\mathrm{ND}$ & $\mathrm{ND}$ & $\mathrm{ND}$ & 44 & 440 & 4,400 \\
\hline Fluorene & ND & ND & ND & 44 & 440 & 4,400 \\
\hline $\mathrm{HpCDD}$ & $1.2 \times 10^{-6}$ & $1.2 \times 10^{-5}$ & $1.2 \times 10^{-4}$ & $3.3 \times 10^{-6}$ & $3.3 \times 10^{-5}$ & $3.3 \times 10^{-4}$ \\
\hline $\mathrm{HpCDF}$ & $1.2 \times 10^{-6}$ & $1.2 \times 10^{-5}$ & $1.2 \times 10^{-4}$ & $3.3 \times 10^{-6}$ & $3.3 \times 10^{-5}$ & $3.3 \times 10^{-4}$ \\
\hline Indeno $(1,2,3-\mathrm{c}, \mathrm{d})$ pyrene & $9.2 \times 10^{-3}$ & $9.2 \times 10^{-2}$ & 0.92 & ND & $\mathrm{ND}$ & ND \\
\hline Naphthalene & ND & ND & ND & 36 & 360 & 3,600 \\
\hline OCDD & $1.2 \times 10^{-5}$ & $1.2 \times 10^{-4}$ & $1.2 \times 10^{-3}$ & $3.3 \times 10^{-5}$ & $3.3 \times 10^{-4}$ & $3.3 \times 10^{-3}$ \\
\hline \multicolumn{7}{|c|}{ 1 } \\
\hline \multicolumn{7}{|c|}{ Groundwater - Measured Concentrations } \\
\hline Arsenic & 0.17 & 1.7 & 17 & 0.044 & 0.44 & 4.4 \\
\hline Aluminum & ND & ND & ND & 15 & 150 & 1,500 \\
\hline Manganese & $\mathrm{ND}$ & ND & ND & 0.73 & 7.3. & 73 \\
\hline Nitrate & $\mathrm{ND}$ & ND & ND & 15 & 150 & 1,500 \\
\hline 2 & HYpo & 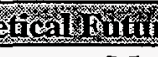 & 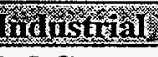 & $01+2$ & & \\
\hline \multicolumn{7}{|c|}{ Groundwater - Modeled Concentrations } \\
\hline 1,1,2-Trichloroethane & 5.1 & 51 & 510 & 0.58 & 5.8 & 58 \\
\hline 1,2-Dichloroethane & 3.2 & 32 & 320 & ND & ND & ND \\
\hline Acetone & ND & ND & ND & 15 & 150 & 1,500 \\
\hline Benzo(a)anthracene & $4.0 \times 10^{-2}$ & 0.40 & 4.0 & ND & $\mathrm{ND}$ & ND \\
\hline Benzo(a)pyrene & $4.0 \times 10^{-2}$ & 0.40 & 4.0 & $\mathrm{ND}$ & $\mathrm{ND}$ & $\mathrm{ND}$ \\
\hline Benzo(b)fluoranthene & $4.0 \times 10^{-2}$ & 0.40 & 4.0 & $\mathrm{ND}$ & ND & $\mathrm{ND}$ \\
\hline Dibenz (a,h)anthracene & $4.0 \times 10^{-2}$ & 0.40 & 4.0 & $\mathrm{ND}$ & ND & ND \\
\hline Dibenzofuran & ND & $\mathrm{ND}$ & $\mathrm{ND}$ & 0.58 & 5.8 & 58 \\
\hline Indeno $(1,2,3-c, d)$ pyrene & $4.0 \times 10^{-2}$ & 0.40 & 4.0 & $\mathrm{ND}$ & $\mathrm{ND}$ & ND \\
\hline Naphthalene & ND & $\mathrm{ND}$ & $\mathrm{ND}$ & 5.8 & 58 & 580 \\
\hline
\end{tabular}

NOTES: $\quad$ HpCDD $=$ Heptachlorodibenzo-p-dioxin

$\mathrm{HpCDF}=$ Heptachlorodibenzo furan

OCDD = Octachlorodibenzo-p-dioxin

$\mathrm{ND}=$ No Data/Not Applicable 
D-Area Burning/Rubble Pits (431-D and 431-1D) Corrective Measures Study/Focused Feasibility Study (U) Savannah River Sitc

March 15, 1996

WSRC-RP-95-904

Revision 1

. Page 21 of 46

Risks or hazards which exceed EPA's thresholds $\left(1 \times 10^{-4}\right.$ to $1 \times 10^{-6}$ or HI>1) were identified for very conservative future use scenarios. The scenarios assume that a family establishes a self-sufficient residency on the waste unit and lives there for 30 years. Included in the assumptions is the fact that the family installs a well in the shallow aquifer used for drinking water, irrigation, and all other domestic water uses. Because the assumptions in the analysis are so conservative, as well as the assumptions in the modeling of soil concentrations to the groundwater, the higher end of the EPA threshold for risk, $1 \times 10^{-4}$, was used as the acceptable risk limit for a particular pathway. Pathways which resulted in risks lower than $1 \times 10^{-4}$ were considered acceptable due to the conservatisms in the analysis, and the fact that the unit is included within the boundary of the Savannah River Site and its release to the public for residential purposes would not occur for some time, if at all.

Based on current groundwater concentrations, arsenic is the most significant contributor to risk and noncarcinogenic hazard, however, this contaminant was found in only one quarter of sampling in only one well at the unit. Later analyses of that same well indicate that arsenic is below the detection limit. Arsenic, therefore, was not considered to be a $\mathrm{COC}$ in the measured groundwater. A few other metals and inorganics measured in the groundwater were calculated to contribute to the noncarcinogenic hazard. The other metals/inorganics include: aluminum, fluoride, manganese, mercury, and nitrate plus nitrite as nitrogen. All of these measured groundwater constituents were eliminated as COCs based on comparisons with MCLs, recommended dietary allowances, and comparisons to background concentrations. A comparison of the concentrations to these values and an explanation for their elimination as COCs is provided in WSRC, 1995a. For the modeled groundwater concentrations, very conservative assumptions were used, which resulted in several contaminants exceeding the threshold values for the carcinogenic risk and noncarcinogenic hazards.

Using EPA default equations, PRGs were calculated in the BRA (WSRC, 1994a) for those COCs which were identified as the primary contributors to potential cancer risk and/or noncancer hazard for the future on-unit resident scenario. The range identifies PRGs which would result in potential cancer risks between $1 \times 10^{-4}$ and 1 $\times 10^{-6}$ and noncancer hazards (hazard indices) between 0.1 and 10 . In addition to contribution to risk, the contaminant concentrations due to the DBRP were compared with Applicable, Relevant, and Appropriate Requirements (ARARs). The following is a summary of the results of the comparisons to ARARs by media:

Soil and Sediments: The Toxic Substances Control Act (TSCA; 40 CFR Part 761) was reviewed for limits of PCBs in the soil. The maximum PCB concentration in the soil is $3.4 \mathrm{mg} / \mathrm{kg}$ which is below the 10 $\mathrm{mg} / \mathrm{kg}$ standard for non-restricted areas. A to-be-considered ARAR for PCBs is EPA's A Guide on Remedial Actions at Superfund Sites With PCB Contamination (EPA, 1990b). This guidance suggests a residential PCB action level of $1 \mathrm{mg} / \mathrm{kg}$. The action level for industrial land use is $10-25 \mathrm{mg} / \mathrm{kg}$. Using this guidance, the soil in DBRP exceeds this ARAR. Health and Environmental Protection Standards for Uranium and Thorium Mill Tailings (40 CFR 192 Subparts A through E) and Radiation Protection of the Public and the Environment (DOE Order 5400.1) were reviewed for limits of radium in the soil. The average total radium level detected in the BRP soils $(1.03 \mathrm{pCi} / \mathrm{g})$ meets the requirements specified by these ARARs.

Initial RAOs developed for the soil, were compared to the detected soil concentrations in each of the borings to provide a geographical sketch of where the soil contamination exceeds the preliminary RAOs. From this comparison (provided in Appendix B), it was shown that the preliminary RAO for arsenic was well below all unit specific background detections. The preliminary RAO was also well below the SRS background values for arsenic. Since arsenic was used as a component of agricultural chemicals in the period before SRS existed, setting an RAO below unit specific background and SRS background values was considered inappropriate. The adjusted RAO for arsenic was set at a limit to achieve a target risk of $I \times 10^{-5}$ and within the range of SRS background values.

It appears from viewing the data geographically, that the polycyclic aromatic hydrocarbons (PAHs) are concentrated in soil boring 13, deeper than 4 feet below surface. Soil boring 13 is suspect as a "hot spot", however, the sampling population is insufficient to confirm this suspicion. Analyses from other pit borings do 
not indicate that the contamination is a product of migration from another location, or that the contamination is migrating out of the pits.

Surface Water: Surface water ARARs include the Federal Ambient Water Quality Criteria (AWQC) for non-drinking water sources and MCLs for drinking water sources. The only contaminants found in the surface water for which an AWQC exists are arsenic, iron, and toluene. The maximum detected concentration of arsenic does not exceed the freshwater $A W Q C$ for the protection of aquatic life. The levels of iron and toluene in the surface water near the BRPs do not exceed the acute toxicity AWQCs for the protection of aquatic organisms. Since the surface water is not used as a drinking water source, the AWQC for the protection of human health is not applicable.

Groundwater: The only constituent observed in the groundwater which exceeds its corresponding MCL is gross alpha. Manganese, iron, and aluminum exceed secondary MCLs, however, these are not applicable since secondary MCLs were promulgated for community and non-community drinking water supplies (for aesthetic qualities). Based on the conservative groundwater modeling calculations, the following chemicals may exceed MCLs in the future:

$\begin{array}{ll}\text { benzene } & \text { dichloromethane } \\ \text { benzo(a)anthracene } & \text { endrin } \\ \text { benzo(b)fluoranthene } & 1,2 \text {-dichloroethane } \\ \text { benzo(k)fluoranthene } & 1,1,2 \text {-trichloroethane } \\ \text { chrysene } & \end{array}$

The RAOs are to reduce the carcinogenic risk and noncarcinogenic hazard (hazard index) to less than $1 \times 10^{-4}$ and 1 , respectively, from dermal exposure to and ingestion and inhalation of modeled (from soil concentrations) groundwater to the future on-unit resident adult and child. Additionally, the RAOs are to comply with ARARs for the current as well as the modeled future conditions of each of the media. RAOs. were developed from the calculated, risk-based PRGs and the comparison with ARARs. Where applicable, the PFGs developed for groundwater were ratioed with soil concentrations to identify the RAOs in the appropriate media. This comparison method allows the RAOs to target the contaminants in the media in which they currently exist and develops objectives which are protective of future groundwater conditions.

Tables 2-2 and 2-3 identify the groundwater PRGs and the preliminary soil RAOs, respectively. In comparing the preliminary RAOs with the soil analysis data (Appendix B), it is evident that some RAOs are near or below unit specific background concentrations; these contaminants include arsenic, HPCDD, and OCDD. 
D-Area Burning/Rubble Pits (431-D and 431-1D) Corrective Measures Study/Focused Feasibility Study (U) Savannah River Site

Table 2-2 Groundwater Preliminary Remediation Goals (PRGs)

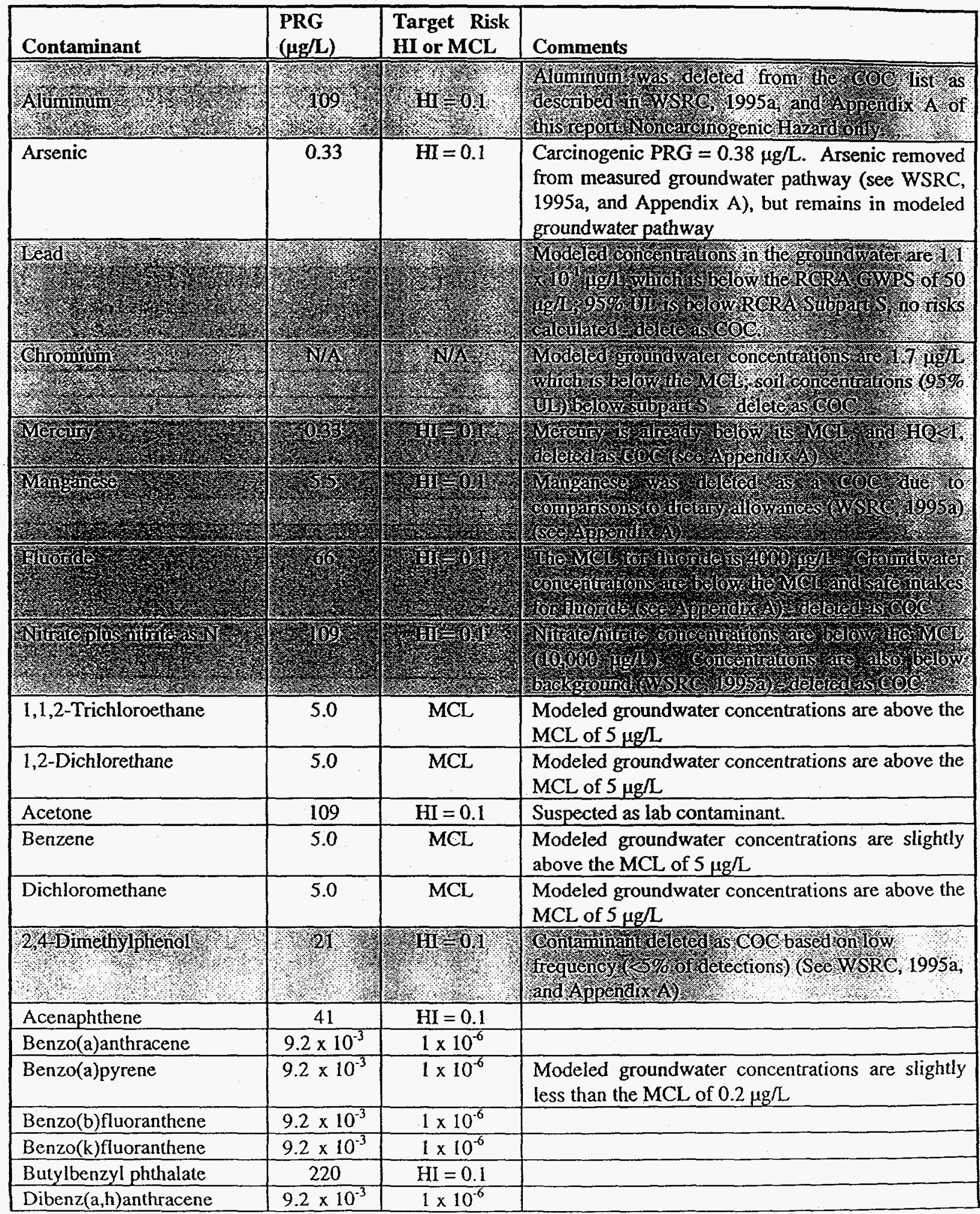


D-Area Burning/Rubble Pits (431-D and 431-1D) Corrective Measures Study/Focused Feasibility Study (U) Savaniah River Site

March 15, 1996

Table 2-2 Groundwater Preliminary Remediation Goals (PRGs) (continued)

\begin{tabular}{|c|c|c|c|}
\hline Contaminant & $\begin{array}{l}\text { PRG } \\
(\mu g / L)\end{array}$ & $\begin{array}{l}\text { Target Risk } \\
\text { HI or MCL }\end{array}$ & Comments \\
\hline Dibenzofuran & 4.0 & $\mathrm{HI}=0.1$ & \\
\hline 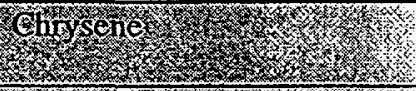 & 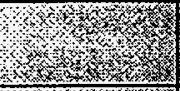 & Mry & 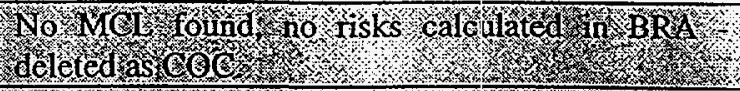 \\
\hline Phenanirivg & 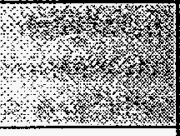 & 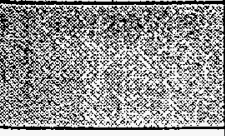 & 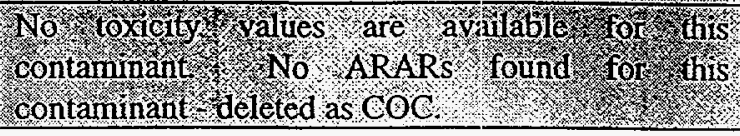 \\
\hline 2-Methylnaphthalene & 27 & $\mathrm{HI}=0.1$ & \\
\hline Fluoranthene & 44 & $\mathrm{HI}=0.1$ & \\
\hline 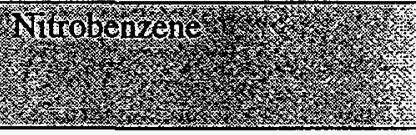 & 3.t. & Prom & 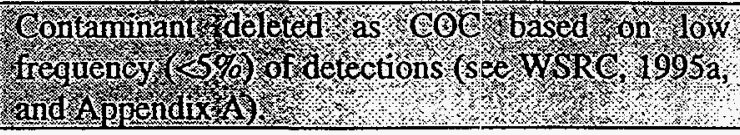 \\
\hline Naphthalene & 36 & $\mathrm{HI}=0.1$ & \\
\hline Indeno $(1,2,3-c d)$ pyrene & $9.2 \times 10^{-3}$ & $1 \times 10^{-6}$ & \\
\hline $\mathrm{HpCDD}$ & $1.2 \times 10^{-6}$ & $1 \times 10^{-6}$ & \\
\hline 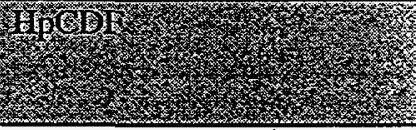 & 1.t. & 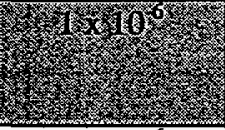 & 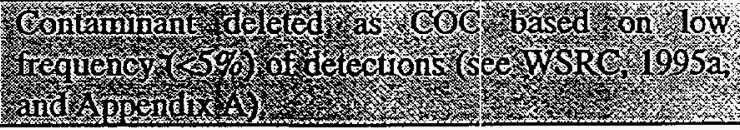 \\
\hline OCDD & $1.2 \times 10^{-5}$ & $1 \times 10^{-6}$ & \\
\hline 1) & (3) & 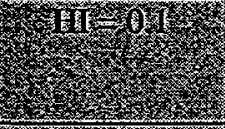 & 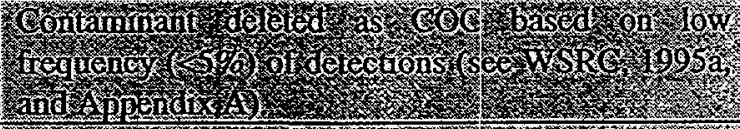 \\
\hline 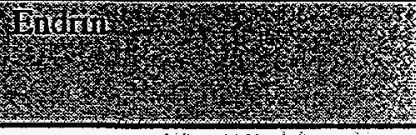 & 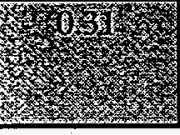 & 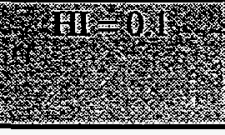 & 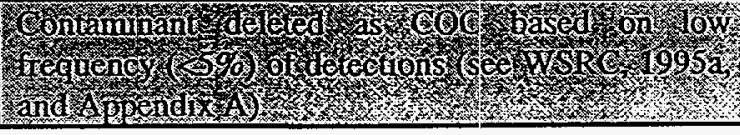 \\
\hline
\end{tabular}

Note: Shaded contaminants were eliminated as COCs. 
Table 2-3 Preliminary Remedial Action Objectives for DBRP Soils

\begin{tabular}{|c|c|}
\hline Contaminant & $\begin{array}{c}\text { Soil } \\
\mathrm{mg} / \mathrm{kg}\end{array}$ \\
\hline 1,1,2-Trichloroethane & $2.2 \times 10^{-3}$ \\
\hline 1,2-Dichlorethane & $1.3 \times 10^{-3}$ \\
\hline 2- Methylnaphthalene & $3.7 \times 10^{-1}$ \\
\hline Acenaphthene & $3.5 \times 10^{-1}$ \\
\hline Acetone & $1.4 \times 10^{-2}$ \\
\hline Arsenic & $23 \times 10^{-1}$ \\
\hline Benzene & $2.4 \times 10^{-3}$ \\
\hline Benzo(a)anthracene & $2.3 \times 10^{-2}$ \\
\hline Benzo(a)pyrene & $9.0 \times 10^{-2}$ \\
\hline Benzo(b)fluoranthene & $9.0 \times 10^{-3}$ \\
\hline Benzo(k)fluoranthene & $9.1 \times 10^{-3}$ \\
\hline Butylbenzyl phthalate & $2.1 \times 10^{-1}$ \\
\hline Dibenz(a,h)anthracene & $5.4 \times 10^{-2}$ \\
\hline Dibenzofuran & $6.0 \times 10^{-2}$ \\
\hline Dichloromethane & $2.0 \times 10^{-3}$ \\
\hline Fluoranthene & $3.0 \times 10^{-0}$ \\
\hline 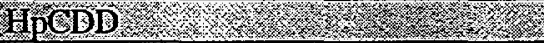 & $71 \times 10^{\circ}$ \\
\hline Indeno(1,2,3-cd)pyrene & $2.6 \times 10^{-2}$ \\
\hline Naphthalene & $4.7 \times 10^{-2}$ \\
\hline OGOD & $3 \times 21 \times 1018$ \\
\hline PCBs (residential land use) & 1 \\
\hline PCBs (industrial land use) & 10 \\
\hline
\end{tabular}

* Shaded contaminants have RAOs at or below unit specific background concentrations

There is a risk based hazard associated with $\mathrm{PCB}-1260$ (78\% of the associated risk), B(a)P (10\%), and OCDD (9\%) for future residents from ingestion of the soil. The maximum level of these compounds found in the DBRP resulted in a risk of $1 \times 10^{-5}$ for future residents. The risk for future workers was $1 \times 10^{-6}$ which is at the lower end of the EPA's target risk range and would thus not require remediation. The remedial action objective for a residential future land use scenario is to reduce the levels of PCB-1260, B(a)P, and OCDD so that the risk is less than or equal to $1 \times 10^{-6}$.

\subsection{General Response Actions}

General response actions are those actions that will satisfy the RAOs. These actions are medium-specific. Since there are currently no COCs in the groundwater (measured concentrations), no general response actions were developed for this medium. Response actions for soil include no action, institutional controls, soil cover, soil treatment, and soil disposal. 


\subsection{Identification of Technology Types and Process Options}

An initial determination of the area or volumes of media to which general response actions might be applied was made for the DBRP. Since relatively low levels of contamination were found in the various media in and around the pits, RAOs were established only for the soil within the pits. The PCB-1260 was found primarily in the top two foot layer of the pits. The general response actions used to achieve the remedial action objectives will, therefore, only be applied to the top two feet of soil and debris within the DBRP.

The dimensions of the pits are as follows:

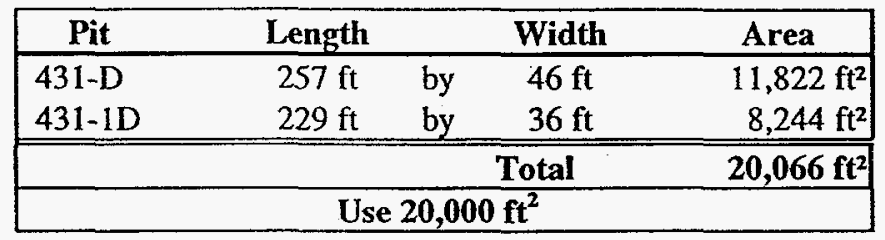

If only the top two foot layer is considered for remediation, then the volume of soil and debris to be remediated becomes $40,000 \mathrm{ft}^{3}$.

\subsubsection{Identification of Options for Soil Treatment}

The five general response actions are described in the following sections.

\subsubsection{No Action}

The No Action option is required by the NCP to serve as the baseline for comparison with other remediation methods. No action is not actually a technology, but is a general response action. The no action alternative can rely on natural attenuation mechanisms to reduce contaminant concentration levels to below proposed concentration-based remediation goals. It is a suitable alternative for scenarios where the risks have been found to be within acceptable limits.

\subsubsection{Institutional Controls}

Institutional controls are administrative measures taken to minimize the potential for human exposure. Institutional controls would consist of filing deed restrictions or notifications and performing five year ROD reviews. Deed restrictions and notifications would inform hypothetical developers or buyers of previous hazardous waste disposal activities at the unit, and would limit the types of future activities that could be conducted on the property (e.g., restrictions on excavating and groundwater use).

Institutional controls would be effective in further minimizing the potential for human exposure to DBRP contaminants and would be relatively easy to implement. In addition, costs associated with institutional controls are considered low relative to other remedial responses. Institutional control costs would include surveying costs, the costs for filing deed restrictions or notifications, and preparation of five year ROD reviews. Five year ROD reviews are required for any waste site that has provisions which prevents unrestricted land use. 


\subsubsection{Native Soil Cover (4')}

This option consists of placing a layer of clean soil over the contaminated DBRP. The additional layer of soil serves as a barrier to help prevent future receptors from becoming exposed to contamination contained within the soil of the DBRP. The depth of soil used is determined by the hazards contained in the waste unit and the future land use proposed for the this waste unit. The Citizens Advisory Board (CAB) has recommended that the land surrounding D-Area, including the DBRP, be classified as an industrial zone for future land use planning.

\subsubsection{Remedial Treatment Technology}

The remedial treatment technology considered is thermal desorption/incineration. This option consists of removing the first two feet of soil, passing it through a rotary kiln which vaporizes the volatile and semivolatile organic materials present, and sending this vapor stream through an incinerator which decomposes the hazardous organics to harmless materials. The remediated soil can then be returned to the DBRP and the unit can be released for unrestricted use. Risks were shown in the 0-4 ft layer of soil, however, the risks are nearly unchanged when the 0-2 $\mathrm{ft}$ layer is compared to the $0-4 \mathrm{ft}$ layer. This indicates that nearly all of the risk is from the 0-2 $\mathrm{ft}$ layer and thus only this layer needs to be remediated. This option can probably be completed within 6 months to one year.

\subsubsection{Offsite Soil Disposal}

This option consists of excavating the top two foot layer of soil and shipping it to a licensed waste facility designed to handle PCB contaminated soil. Chem Waste Management, Inc., in Emile, AL is a relatively close facility that can accept this waste. They charge $\$ 275 /$ ton plus an additional waste disposal tax of $\$ 51 /$ ton. The costs for this alternative would include excavation of the contaminated soil, transportation to Emile, AL, waste disposal costs, and costs for refilling the pit with clean soil and revegetating the area. This alternative can be completed in less than six months. The site would be considered remediated and available for unrestricted future land use.

\subsection{Development of Alternatives}

The five general response actions which will be combined into alternatives have already been determined through meetings with SCDHEC and the EPA. Five alternatives have been formed from these general response actions and are listed in Table 2-4.

Table 2-4 Summary of the Alternatives Selected

\begin{tabular}{|c|l|}
\hline Alternative & Description \\
\hline \hline 1 & No Action \\
\hline 2 & Institutional Controls \\
\hline 3 & Native Soil Cover (4') \\
\hline 4 & Thermal Desorption/Incineration \\
\hline 5 & Offsite Soil Disposal \\
\hline
\end{tabular}




\subsection{DETAILED ANALYSIS OF ALTERNATIVES}

\subsection{Introduction}

Detailed analysis of alternatives is required by the NCP (40 CFR 300.430(e)(9)). In this section, the alternatives formulated in Section 3 are evaluated in detail against CERCLA requirements. Following is a discussion of the evaluation criteria used to perform the detailed analysis of alternatives.

The statutory requirements that guide the evaluation of remedial alternatives in an FS (or FFS) are that a remedial action must:

- be protective of human health and the environment

- attain ARARs or define criteria for invoking a waiver

- be cost effective

- use permanent solutions, with a preference for treatment, to the maximum extent

EPA has established nine evaluation criteria to address these statutory requirements for CERCLA. The criteria fall into the categories of threshold criteria, primary balancing criteria, and modifying criteria. Section 3.2 presents an evaluation of each potential remedial alternative based on threshold and primary balancing criteria. Modifying criteria (State or support agency acceptance and community acceptance) will be reevaluated after the public comment period on the CMS/FFS and Proposed Plan (PP). Evaluation criteria categories and the nine evaluation criteria are listed and explained below.

\subsection{Threshold Criteria}

Threshold criteria (overall protection of human health and the environment, and compliance with ARARs) are requirements that each altemative must achieve in order to be eligible for selection as a permanent remedy.

1) Overall protection of human health and the environment - The overall protection of human health and the environment is evaluated for each alternative on the basis of how the alternatives reduce the risk of exposure to contaminants from potential exposure pathways through engineering or institutional controls. Each alternative is also examined as to whether it creates any unacceptable short-term risks to human health.

2) Compliance with ARARs - Location-specific and chemical-specific ARARs were identified and screened for relevance to the DBRP waste unit. Action-specific ARARs pertaining to individual alternatives or remedial technologies are evaluated during detailed analyses.

\subsubsection{Primary Balancing Criteria}

Primary balancing criteria (long-term effectiveness and permanence; short-term effectiveness; reduction of mobility, toxicity, or volume through treatment; implementability; and cost) are factors that identify key tradeoffs among alternatives.

3) Long-term effectiveness and permanence - Long-term effectiveness and permanence are evaluated for each alternative on the basis of the magnitude of residual risk and the adequacy and reliability of controls used to manage remaining waste after response objectives have been achieved. Alternatives 
that offer long-term effectiveness and permanence halt or otherwise mitigate any potential for off-site contaminant transport and minimize the need for future engineering controls.

4) Short-term effectiveness - Evaluation of alternatives for short-term effectiveness takes into account protection of remedial workers, members of the community, and the environment during implementation of the remedial action and the time required to achieve cleanup goals. Schedule estimates are based on projected availability of materials and labor and may have to be updated at the time of remediation. Construction schedules are based on good weather, the ability to create and receive adequate and authorized access, and the availability of required utilities. All time estimates assume that the selected remedial design, including construction drawings, have been approved and all negotiations with contractors have been concluded.

5) Reduction of mobility, toxicity, or volume through treatment - The statutory preference is to select a remedial action that employs treatment to reduce the toxicity, mobility, or volume of hazardous substances. The degree to which alternatives employ recycling or treatment is assessed, including how treatment is used to address the principal threats posed by the site.

6) Implementability - Each altemative is evaluated with respect to the technical and administrative feasibility of implementing the altemative as well as the availability of necessary equipment and services. This criterion includes such items as the ability to obtain services, capacities, equipment, and specialists necessary to construct components of the alternatives; the ability to operate the technologies and monitor their performance and effectiveness; and the ability to obtain necessary approvals from other agencies.

7) Cost - Accuracy of present worth costs is $+50 /-30$ percent, per EPA guidance. Detailed cost estimates are derived from current information including vendor quotes, conventional cost estimating guides (i.e., Means Site Work Cost Data), and costs associated with similar projects. The actual costs of the project would depend on labor and material costs, site conditions, competitive market conditions, final project scope, and implementation schedule at the time that the remedial activities are initiated. In estimating the present worth costs, a discount rate of 5 percent is used and inflation is assumed to be 0 percent. Present worth costs for review of Site remedy every five years are given for each alternative in which residuals would remain at the Site. Present worth costs for these items are based on 30 years of operation, the maximum time allowed by EPA guidance.

\subsubsection{Primary Modifying Criteria}

Modifying criteria (state or support agency acceptance; community acceptance) will be considered during remedy selection.

8,9) State or support agency acceptance and community acceptance - The preferred alternative should be acceptable to state and support agencies. Also, the concerns of the community should be considered in presenting alternatives that would be acceptable to the community. An initial assessment of the likely acceptance by the state and the community is made within this document based on other remedial actions previously proposed at the Savannah River Site. Final acceptance is made through comments to the CMS/FFS and the PP prior to finalization in the ROD. 
D-Area Burning/Rubble Pits (431-D and 431-1D) Corrective Measures Study/Focused Feasibility Study (U) Sayannah River Site

March 1S, 1996

\subsection{Individual Analysis of Alternatives}

The five remedial alternatives selected for the DBRP contaminated soil are evaluated against the nine CERCLA criteria in the following sections.

\subsection{Alternative I - No Action}

Under the No Action alternative, no remedial efforts would be conducted to remove, treat, or otherwise lessen the toxicity, mobility, or affected volume of contaminated soil. All contaminated soil would remain in place. No treatment would be performed.

\section{Overall Protection of Human Health and the Environment}

Alternative 1 would not be protective of human health. The No Action alternative would not eliminate or minimize potential routes for human exposure nor would it involve treatment to reduce the inherent risk associated with contaminated media. The risk from PCB-1260 via ingestion of soil for the intervals of 0 to $2 \mathrm{ft}$ and 0 to $4 \mathrm{ft}$ are both at $1 \times 10^{-5}$, which is within the EPA's target risk range. This alternative will do nothing to further reduce the risk below the $1 \times 10^{-6}$ level.

\section{Compliance with ARARs}

\section{Chemical-Specific ARARs}

There are no radioactive or nonradioactive chemical-specific ARARs for soil under Federal and South Carolina regulations. One to-be-considered (TBC) regulation for PCBs is governed by TSCA (40 ClFR Part 761). For non-restricted access areas (e.g., residential), the PCB cleanup standard is $10 \mathrm{mg} / \mathrm{kg}$ by weight, provided that the soil is excavated to a minimum depth of 10 inches and that the excavated soil is replaced.with clean soil (i.e., soil containing less than $1 \mathrm{mg} / \mathrm{kg}$ PCBs). A to-be-considered ARAR for PCBs is EPA's A Guide on Remedial Actions at Superfund Sites With PCB Contamination (EPA, 1990b). This guidance suggests a residential PCB action level of $1 \mathrm{mg} / \mathrm{kg}$. The action level for industrial land use is $10-25 \mathrm{mg} / \mathrm{kg}$. Using this guidance, the soil in DBRP exceeds this ARAR. The only PCB congener detected in the DBRP was PCB-1260, detected at a maximum concentration of $3.4 \mathrm{mg} / \mathrm{kg}$. This concentration exceeds the residential land use ARAR of $1 \mathrm{mg} / \mathrm{kg}$, thus this alternative would not meet the chemical-specific ARARs for residential use.

\section{Location-Specific ARARs}

No location-specific ARARs are associated with Alternative 1.

\section{Action-Specific ARARs}

No action-specific ARARs are associated with Alternative 1.

\section{Long-Term Effectiveness and Permanence}

Long-term effectiveness and permanence would not be achieved with this alternative. Risk due to soil ingestion from PCB-1260 would remain at $1 \times 10^{-5}$. This alternative would provide long-term protection of the environment as the BRA found no risks to the environment posed from the contaminants in the DBRP. 
Reduction of Toxicity, Mobility, or Volume

The No Action alternative would not involve any form of active treatment that would reduce contaminant or contaminated soil toxicity, mobility, or volume.

\section{Short-Term Effectiveness}

The No Action alternative would satisfy short-term protection of human health as there are no risks to current workers or visitors to this area. There are no risks to remediation workers, the community, or the environment from this alternative.

Implementability

This alternative can be readily implemented.

\section{$\underline{\operatorname{Cost}}$}

There are no costs associated with the No Action alternative.

\section{State Acceptance}

No action is not likely to be acceptable to the state. The risk determined in the BRA is $1 \times 10^{-5}$ to future residents from ingestion of the soil. This risk is within the EPA's target risk range. Consideration is being given to reduce this risk to a level of $1 \times 10^{-6}$ or less.

\section{Community Acceptance}

No action may not be acceptable to the community for similar reasons.

\subsubsection{Alternative 2 - Institutional Controls}

In this alternative, deed restrictions would be placed in the Barnwell County Records on the waste units which would restrict the use of this land to industrial use only. A deed notification would also be filed indicating that this area was used to manage hazardous waste. ROD reviews would be provided every five years for 30 years. These deed restrictions would provide protection to human health in case the land ever becomes available for public use. Groundwater use would also be restricted.

\section{Overall Protection of Human Health and the Environment}

Alternative 2 would be protective of human health as long as the waste units are maintained for industrial use only. For future industrial workers, the risk from PCB-1260 from ingestion of soil for the intervals of 0 to $2 \mathrm{ft}$ and 0 to $4 \mathrm{ft}$ are both at the lower limit of the EPA's target risk range $\left(1 \times 10^{-6}\right)$, therefore, the contaminated soil will not cause a risk to human receptors exceeding one additional cancer in one million people.

\section{Compliance with ARARs}

\section{Chemical-Specific ARARs}

This alternative would comply with the PCB ARAR which limits PCB concentration to $10 \mathrm{mg} / \mathrm{kg}$ or less for industrial land use scenarios. The maximum PCB concentration found in the top four foot layer was $3.4 \mathrm{mg} / \mathrm{kg}$. 


\section{Location-Specific ARARs}

No location-specific ARARs are associated with Alternative 2.

\section{Action-Specific ARARs}

No action-specific ARARs are associated with Alternative 2.

\section{Long-Term Effectiveness and Permanence}

This alternative would provide long-term effectiveness as long as the deed restrictions are enforced. This alternative does not provide permanence as no action is taken to remove or destroy the contaminants.

Alternative 2 would provide long-term protection of the environment as the BRA found no risks to the environment posed from the contaminants in the DBRP.

\section{Reduction of Toxicity, Mobility, or Volume}

This alternative would not involve any form of active treatment that would reduce contaminant or contaminated soil toxicity, mobility, or volume.

\section{Short-Term Effectiveness}

This alternative would provide short-term effectiveness. There would be no risk to remedial workers, the community, or the environment to implement this action.

Implementability

Alternative 2 can easily be implemented. Adding deed restrictions to this land to prevent residential use is a simple procedure.

\section{Cost.}

The capital costs for this alternative would be for performing a survey of the waste units, filing deed restrictions and deed notifications with the Barnwell County Records, and providing ROD reviews every five years for 30 years. The costs for the deed filings and a site survey plat are estimated to be $\$ 2,000$. Additional costs would be incurred for performing 5 year ROD reviews. The EPA specified that they are drafting supplemental guidance clarifying what a Federal agency's responsibilities are for five year reviews. Until this guidance is published, it can only be speculated as to what is involved. The estimate used here was for a $\$ 3,000$ cost performed every five years for 30 years. The present value cost is $\$ 8,346$ using a $\$ \%$ interest rate. This would include one person visually inspecting the site to determine how the site is currently being used, listing any changes since the previous report, and reviewing any local downgradient soil or groundwater samples tested within the previous five year period. A letter would then be written to the regulators stating the findings. If EPA guidance requires more extensive activity, then this estimate would be too low. The total present value cost is estimated to be $\$ 10,346$. 
State acceptance of this alternative may be achieved if the regulators feel that institutional controls provide sufficient protection to human health at this site. This site poses a risk only to future residents from ingestion of soil. ARARs are met under industrial land use scenarios.

\section{Community Acceptance}

The community would likely accept this alternative. The $\mathrm{CAB}$ has recommended that this area be designated for future industrial use only. The risk in this area is reduced to $1 \times 10^{-6}$ for future on-unit workers. All ARARs are met in the industrial land use scenario.

\subsubsection{Alternative 3 - Native Soil Cover (4')}

In this alternative, a four foot layer of soil is placed over the pits. This cover is feathered into the surrounding area to help prevent erosion. Deed restrictions would be filed to prohibit groundwater use. Deed notifications would be filed to indicate that the land was used to manage hazardous materials.

\section{Overall Protection of Human Health and the Environment}

This alternative would be protective of human health and the environment. The four foot layer of soil effectively prevents future residents from ingesting contaminated soil. Typical residential excavation activities such as digging fence posts, gardening, etc. would not likely bring contaminated soil to the surface. Deed notifications would serve to inform future residents that the area was used to manage hazardous materials and that excavation beyond four feet should be avoided. Deed restrictions prohibiting groundwater use would also be added.

\section{Compliance with ARARs}

\section{Chemical-Specific ARARs}

This alternative would meet the to-be-considered guidance which states that the PCB action level for residential land use is $1 \mathrm{mg} / \mathrm{kg}$. This guidance covers the top four foot layer of soil.

\section{Location-Specific ARARs}

No location-specific ARARs are associated with this alternative.

\section{Action-Specific ARARs}

No action-specific ARARs are associated with this alternative.

\section{Long-Term Effectiveness and Permanence}

This alternative would provide long-term effectiveness as long as the deed restrictions are enforced. This alternative does not provide permanence as no action is taken to remove or destroy the contaminants. Alternative 3 would provide long-term protection of the environment as the BRA found no risks to the environment posed from the contaminants in the DBRP. 
The addition of a four foot layer of native soil will help to reduce the mobility of the contaminants. The major risk for this waste site is ingestion of soil from PCB-1260. The layer of native soil will effectively prevent the contaminated soil from becoming airborne as dust which could then be ingested by future residents. The four foot layer also makes it highly unlikely that future residents will get contaminated soil on their hands or clothing which could eventually be ingested. Neither the toxicity nor the volume of contaminated soil is reduced by this alternative.

\section{Short-Term Effectiveness}

Adding the layer of native soil would provide a minimal risk to the workers due to the operation of heavy equipment. Proper use of safety equipment and strict compliance with safety procedures and OSHA regulations should reduce this risk to acceptable levels. There is also a slight risk to the environment from this alternative. The soil removal must be done in a manner which limits disruption of wildlife. The remediation contractor must carefully select the site for removal of the native soil to limit any effects to the environment. Vegetation should be replaced when the task is completed. Erosion controls must be in place while remediation is in progress.

There will not be any risk to the community while this remediation is being undertaken.

\section{Implementability}

This alternative is easily implemented. Native soil is readily available from a number of locations on site. Deed restrictions can easily be instituted. Contractors to excavate and transport the cover soil and spread it over the waste site are readily available.

\section{$\underline{\text { Cost }}$}

This alternative is estimated to have a present value of $\$ 235,620$. The costs for deed notifications, deed restrictions, and ROD reviews are identical to alternative 2 . The cost for maintenance has been estimated to be $\$ 1,000 / \mathrm{yr}$ to allow for any additional minor costs to remediate erosion damage to the soil cover. The present value for this cost over 30 years is $\$ 15,372$. A Remedial Design/Remedial Action (RD/RA) CERCLA work plan would be prepared for an estimated $\$ 50,000$. The one-time cost for the soil cover was estimated to be $\$ 159,902$. This cover would be feathered into the surrounding area at a ratio of 10 feet of distance for one foot of drop. Three to six months should allow sufficient time to install the cover and establish vegetation.

\section{$\underline{\text { State Acceptance }}$}

State acceptance of this alternative may be achieved if the regulators feel that institutional controls along with a four foot soil cover provides sufficient protection to human health at this site. This site poses a risk only to future residents from ingestion of soil. It has not yet been established whether the State feels that this is sufficient protection for this site. Cover technologies have been approved on other SRS waste sites with comparable COC suites and levels of contamination.

\section{Community Acceptance}

The community would likely accept this alternative. The $\mathrm{CAB}$ has recommended that this area be designated for future industrial use only and may not want to make this land available for residential use. The addition of a four foot thick soil cover may be considered to be sufficient additional protection in order to obtain their acceptance. Cover technologies have been used at other SRS waste sites with good public acceptance. 


\subsubsection{Alternative 4-Thermal Desorption/Incineration}

The top tow foot layer of soil will be excavated and fed to the thermal desorption unit which will volatilize the PCBs. The vapor stream will then be fed to the incinerator which will degrade the PCBs to harmless compounds. The treated soil will be placed back into the pit, leveled, and revegetated. Deed restrictions will be filed to restrict use of the groundwater.

\section{Overall Protection of Human Health and the Environment}

This alternative would be protective of human health. The first two feet of contaminated soil would be removed, as discussed in Section 2.4, and treated to eliminate nearly all of the PCB-1260, B(a)P, and OCDD. This remediation is permanent and would reduce the risk from ingestion of soil to less than $1 \times 10^{-6}$. Deed restrictions would prohibit domestic groundwater use.

\section{Compliance with ARARs}

\section{Chemical-Specific ARARs}

This alternative fully meets the ARAR concerning PCB levels in the soil. The remediated soil is expected to contain much less than $1 \mathrm{mg} / \mathrm{kg}$ of residual PCBs.

Location-Specific ARARs

No location-specific ARARs are associated with this alternative.

\section{Action-Specific ARARs}

The thermal desorption/incineration equipment must meet the Clean Air Act requirements. A National Emission Standards for Hazardous Air Pollutants (NESHAPs) permit will be required for the emissions that may be given off from this process.

\section{Long-Term Effectiveness and Permanence}

This alternative will provide long-term effectiveness and permanence. The PCBs are permanently destroyed in the incineration process.

\section{Reduction of Toxicity, Mobility, or Volume}

The toxicity of the soil is greatly reduced as the contaminants are vaporized during the desorption process and are separated from the soil. The mobility and volume of the contaminants is also reduced as they are destroyed during incineration.

\section{Short-Term Effectiveness}

This alternative does pose additional risks for the remediation workers. Soil excavation poses risks from operating with heavy machinery. There also is potential risk from contacting the exposed contaminated soil. The desorption/incineration process is a high temperature process which poses burn risks. Care must also be taken to avoid breathing vapors emitted during desorption/incineration. Safety equipment must be furnished to minimize potential hazards from this processing. Safety procedures and OSHA regulations must be followed to limit risks to the workers. This process is common in the industry and does not pose inordinate risks to the workers provided safety procedures are strictly followed. 
It is unlikely that the community will be adversely affected by this processing. The unit will require an air permit. Exhaust from malfunctioning equipment could pose risks, however, the location of the waste site is relatively distant from any communities in the unlikely event that the air pollution prevention system malfunctions.

The environment should also not be adversely impacted during proper operation of this equipment. Erosion controls must be in place while the remediation is in progress. Vegetation should be replanted after the process is concluded. Dust control must also be maintained while the operation is in progress.

\section{Implementability}

This alternative can be implemented at the DBRP. This involves well known technology which can be provided by a number of contractors. The rotary kiln and incinerator are large pieces of equipment which must be temporarily relocated to the site for the remediation. Electricity and propane or alternative fuels must be made available for operation. Heavy earthmoving equipment must also be obtained.

All of this equipment is common for these applications and should be available within several months. Remediation is expected to take less than one year once all permits are in order and a remediation contract is signed.

\section{$\underline{\text { Cost }}$}

The total present value cost for this option is $\$ 1,502,000$. This is based on a turnkey contract at a cost of $\$ 30 / \mathrm{ft}^{3}$ (\$810/cubic yard) of soil to be remediated. Several sources were reviewed to estimate the unit cost for thermal desorption of the DBRP contaminated soil. VISITT ${ }^{\mathrm{TM}}$ (EPA, 1994c) has several contractors listed with cost estimates for thermal desorption of contaminated soil ranging from $\$ 15$ to $\$ 1000$ per ton (approximately $\$ 30$ to $\$ 1,400$ per cubic yard). Unit costs listed by the vendors in the VISITT ${ }^{\mathrm{TM}}$ program may not be inclusive of indirect costs, site preparation, soil classification, permit costs, energy costs, air emissions monitoring, etc. These costs are also very dependent on soil conditions (i.e. moisture content, degree of contaminant removal required, and the amount of debris in the soil). An RD/RA work plan would be prepared for an estimated $\$ 150,000$. The administrative costs incurred for obtaining an air permit for the PCB incinerator is expected to cost $\$ 150,000$. Deed restrictions and a survey plat can be made for $\$ 2,000$.

Although not directly comparable, SRS cost estimates for incineration of hazardous waste in the Consolidated Incinerator Facility (CIF) and offsite incineration of hazardous waste were compared. The CIF accepts low level radioactive waste and hazardous waste that can be incinerated, but is not equipped to accept large volumes of soil for incineration. Residual waste from CIF is stabilized in a grout mixture and is placed in disposal vaults for permanent disposal. The incineration of soil does not result in a volume reduction and stabilization of incinerated waste would not be necessary. CIF costs for non-soil incinerable hazardous waste are approximately $\$ 3,500$ per cubic yard (minus waste management costs for handling and storing the waste). Costs for shipment of drummed hazardous waste to an offsite incinerator for permanent disposal is estimated to be approximately $\$ 7,000$ per cubic yard (Taylor, 1993).

WSRC remedial technology experts estimated the cost of thermal desorption/incineration in the DBRP (within $30 \%$ to $+50 \%$ accuracy) as being $\$ 450$ per cubic yard. Based on the wide range of unit costs from the vendor information and estimates for incineration at SRS and commercially, the costs as estimated ty WSRC remedial technology experts was used with an adjustment factor. In order to include costs for excavation, restoration of the site after remediation, site engineering and overhead, and allowing for the remote location of the DBRP (away from any power sources), a multiplier of 1.8 was applied to this estimate. The final unit cost used to estimate the costs for the thermal desorption alternative is $\$ 810$ per cubic yard or $\$ 30 /$ cubic: foot. There is no 
need for five year ROD reviews because the waste has been removed and destroyed. The process will allow complete, unrestricted future use of this land and will not require signs, maintenance, or monitoring.

\section{State Acceptance}

This altemative would likely be acceptable to the state. The treatment effectively remediates the site to background levels and would allow for unrestricted future use of this land.

\section{Community Acceptance}

The community would likely accept this alternative for the same reasons that the state would. There was, however, discussion at a CAB CMS/FS scoping meeting that complete remediation of this site to background levels would not be warranted for a site with such low risk. The statement was made that they would rather see the limited remediation funds spent on sites with a higher level of risk.

\subsubsection{Alternative 5 - Offsite Soil Disposal}

The top two feet of soil will be excavated and shipped to a licensed waste facility. Clean soil will be placed into the pits and revegetated. Deed restrictions will be filed to prohibit groundwater use.

\section{Overall Protection of Human Health and the Environment}

This alternative would be protective of human health and the environment. The first two feet of contaminated soil would be removed and shipped to an offsite waste facility. This remediation is permanent and would reduce the risk from ingestion of soil to less than $1 \times 10^{-6}$.

\section{Compliance with ARARs}

\section{Chemical-Specific ARARs}

This alternative fully meets the ARAR concerning PCB levels in the soil. The clean soil used to refill the pit will contain less than $1 \mathrm{mg} / \mathrm{kg}$ of residual PCBs.

\section{Location-Specific ARARs}

No location-specific ARARs are associated with this alternative.

\section{Action-Specific ARARs}

No action-specific ARARs are associated with this alternative.

\section{Long-Term Effectiveness and Permanence}

This alternative will provide long-term effectiveness and permanence. The soil contaminated with PCBs has been permanently removed from the pits. 


\section{Reduction of Toxicity, Mobility, or Volume}

This alternative does not actually reduce the toxicity of the contaminated soil, however, the toxicity within the remediated pit is reduced to background levels. The mobility of the contaminated soil is somewhat reduced as it has been placed in a facility designed to reduce its mobility. The volume also remains the same.

\section{Short-Term Effectiveness}

This alternative does pose additional risks for the remediation workers. Soil excavation poses risks from operating with heavy machinery. There also is potential risk from contacting the exposed contaminated soil. Safety procedures and OSHA regulations must be followed to limit risks to the workers. This process is common in the industry and does not pose inordinate risks to the workers provided safety procedures are strictly followed.

It is unlikely that the community will be adversely affected by this processing despite the need to transport this material across public roads..

The environment should also not be adversely impacted during remediation. Erosion controls must be in place while the remediation is in progress. Vegetation should be replanted after the pits are backfilled. Dust control must also be maintained while the excavation is in progress. Shipping must follow DOT regulations to avoid possible contamination problems during transportation.

\section{Implementability}

This alternative can be implemented at the DBRP. Earthmoving equipment is readily available. Chem Waste Management, Inc., in Emile, AL is available and permitted to receive this waste.

Remediation should take three to six months.

\section{$\underline{\text { Cost }}$}

The total present value cost for this option is $\$ 1,084,000$. This is based removing $40,000 \mathrm{ft}^{3}$ of contaminated soil, shipping the soil approximately 400 miles to Emile, AL, disposing of the soil in an approved waste facility, and backfilling the pits with clean soil and revegetating. The cost for excavation is estimated to be $\$ 40,000$ based on a $\$ 1 / \mathrm{ft}^{3}$ cost. Transportation was estimated to be $\$ 200,000$ based on a $\$ 5 / \mathrm{ft}^{3}$ cost. The cost for preparing an RD/RA work plan is $\$ 150,000$. Waste disposal costs $\$ 652,000$ based on a waste disposal charge of $\$ 275 /$ ton and a disposal tax of $\$ 51 / \mathrm{ton}$. It was assumed that a cubic foot of soil weighs $100 \mathrm{lb}$. The costs for backfilling the pits with clean soil and revegetating was estimated to be $\$ 40,000$ based on $\$ 1 / \mathrm{ft}^{3}$. The cost for a survey plat and filing a deed restriction is $\$ 2,000$. All of these costs occur in the first year so the present value is simply their sum.

\section{State Acceptance}

This alternative would likely be acceptable to the state. The treatment effectively remediates the site to background levels and would allow for unrestricted future use of this land.

\section{Community Acceptance}

The community would likely accept this alternative for the same reasons that the state vould. There was, however, discussion at a CAB CMS/FS scoping meeting that complete remediation of this site to background 
D-Area Burning/Rubble Pits (431-D and 431-1D) Corrective Measures Study/Focused Feasibility Study (U) Savannah River Sitc

WSRC-RP-95-904 March 15, 1996

levels would not be warranted for a site with such low risk. The statement was made that they would rather see the limited remediation funds spent on sites with a higher level of risk.

\subsection{Comparative Analysis}

In this section, each of the alternatives are compared to each other for each of the nine CERCLA criteria. The alternatives are discussed in the order that they meet the specific criteria.

\section{Overall Protection of Human Health and the Environment}

Alternatives 4 and 5 would give the greatest overall protection of human health and the environment. In these alternatives, virtually all of the PCBs and dioxin compounds would be removed from the top two feet of soil. The resulting soil would exhibit risk no greater than $1 \times 10^{-6}$ for any future resident, adult or child.

Alternative 2 provides better control of the land and thus provides more long-term protection than alternative 3 . This alternative would reduce the risk to $1 \times 10^{-6}$ as long as the property is maintained for industrial use only. This risk remains at $1 \times 10^{-5}$ if the land is ever used for residential purposes.

Alternative 3 also reduces the risk from ingestion of soil to future residents to $1 \times 10^{-6}$. Construction on this site by future residents would present problems in maintaining the lower risk. Placing footer or slabs for housing or trailers could possibly bring contaminated soil to the surface. It also would be very likely that future residents may excavate to install fence posts, playground toys (swings, etc.), or storage buildings. Children may also dig up contaminated soil while playing. It would be very difficult to prevent any of these future activities which could bring contaminated soil to the surface.

Alternative 1 would not change the risk from the levels indicated in the BRA.

\section{Compliance with ARARs}

\section{Chemical-Specific ARARs}

Alternatives 4 and 5 would fully meet the ARAR for PCBs for residential land use. Alternative 2 would fully meet the ARAR for PCBs for an industrial land use scenario. Alternative 3 would also meet the ARAR for residential land use, however, deed notifications serve as the only protection to prevent excavation below four feet which could bring contaminated soil to the surface. Alternative 1 does not meet the ARAR for PCBs for residential use.

\section{Location-Specific ARARs}

No location-specific ARARs are associated with any of these alternatives.

\section{Action-Specific ARARs}

Alternatives 1 through 4 do not have any action-specific ARARs. Alternative 5 would require that NESHAPS air permits are obtained. This technology is well established and the air emissions can easily be controlled. Obtaining the permits and operating to the specified levels should be easily accomplished. 
Long-Term Effectiveness and Permanence

Alternatives 4 and 5 provide permanent remediation solutions which give complete long-term effectiveness. The PCBs and dioxin materials are removed from the soil.

None of the other three alternatives permanently removes the contaminants. Alternative 2 would also provide long-term effectiveness. As long as the DBRP area is retained for industrial use only, the risk levels would be at $1 \times 10^{-6}$ and all ARARs would be met.

Alternative 3 provides relatively long-term effectiveness as the four foot cover should continue to separate human receptors from the contaminated soil. This alternative, however, cannot be expected to permanently remediate the problem since it is not a treatment technology. The cover is susceptible to breaching through excavation or severe erosion. Deed notifications will help prevent excavation in the area. The addition of the soil cover and the deed notifications do provide long-term effectiveness, but they cannot be expected to add permanence to the remediation.

Alternative 1 provides no long-term effectiveness or permanence to this remediation.

\section{$\underline{\text { Reduction of Toxicity, Mobility, or Volume }}$}

Alternative 4 provides nearly complete reduction in the toxicity, mobility, and volume of the contamination. A very high percentage of the PCBs and dioxin materials are removed from the soil during the desorption phase. These contaminants are then broken down into harmless combustion products through the incineration process.

Alternative 5 does not actually reduce the toxicity of the contaminated soil, however, the soil is replaced with clean soil so that the net effect is the toxicity has been totally reduced. The mobility of the contaminated soil is somewhat reduced as it will be placed in a facility designed to reduce its mobility. The volume of contaminated soil remains unchanged.

Alternative 3 reduces the mobility of the contaminants: The main risk is through ingestion of the soil. The four foot thick cover effectively prevents the contaminated soil from becoming airborne where is could be inhaled and ingested, prevents contaminated soil from getting on the hands of residents where it could eventually be ingested, and prevents contaminated soil from coming in contact with homegrown vegetables where it could again be ingested. This alternative does not reduce the toxicity or the volume of the contaminants.

Alternative 2 provides controls to prevent potentially toxic contaminants from causing significant human health risks. Alternatives 1 and 2 will do nothing to reduce the toxicity, mobility, or volume of the contaminated soil.

\section{Short-Term Effectiveness}

Alternatives 1 and 2 provide the greatest short-term effectiveness as they involve no remediation activities on the site. There currently is no risk to onsite workers. The only risk is for future residents. No environmental risks have been identified in the BRA.

Alternatives 3 and 5 would provide higher risks to workers during remediation than alternatives 1 and 2 . Heavy earth-moving equipment would be used during these actions which would pose potential hazards to the workers. This risk would be minimized through the use of OSHA operating procedures. Alternative 3 is unlikely to impact the community. While alternative 5 must transport the soil across public roads, it is unlikely that this activity will adversely impact the community. There could be slight risks to the environment from both of these 
alternatives if erosion control measures were not followed. Alternative 3 would feather the soil cap into the surrounding area to minimize erosion. Vegetation would be restored to help hold the soil in place for both of these alternatives. Both of these alternatives could be completed in three to six months.

Alternative 4 has higher short term risks than any of the other alternatives. This alternative also involves heavy earth-moving equipment which poses a potential safety hazard to the remediation workers. Since the contaminated soil would be excavated, there is a risk that workers could come in contact with the contaminated soil. Dust masks would be provided to minimize this risk. The high temperature equipment used to desorb the contaminates also provides a moderate risk to the workers. Gloves and other insulating equipment would be provided to the affected workers. Fumes emitted from the operation could also potentially harm the workers. The treatment system is provided with an air treatment system designed to meet NESHAPS requirements. The potential for employees inhaling harmful fumes is thus minimized. The system would also protect the community from these fumes. No other potential risks are seen for the community. The environment would be protected through erosion prevention practices. During excavation, silt fences will be used to reduce erosion. The treated soil will be placed back in the original excavation and replanted with vegetation when the project is completed. The entire remediation is expected to take less than one year.

\section{Implementability}

Alternative 1 would be the easiest to implement as it involves no action. Alternative 2 would be relatively easy to implement as deed restrictions can be placed on the land through simple legal actions.

Alternative 3 would include adding a deed notification and placing a four foot soil cover feathered into the surrounding soil to minimize erosion. Vegetation would be replanted on the surface after the soil cover was in place. All of these actions can be completed in three to six months.

Alternative 5 would also be implementable. The soil would be excavated and shipped to an offsite waste facility. Clean soil would be backfilled into the pits and revegetated. All of this should take from three to six months.

Alternative 4 would also be implementable even though this would involve the greatest initial effort. Excavation equipment used in this alternative will be similar to that used for alternatives 3 and 5 . This remediation will require transportation and setup of the desorption/incineration equipment. While this is a major undertaking, it is routinely done for many waste sites and should be considered to be readily implementable. Portable generators and propane tanks will also be required for this operation. NESHAPS permits to regulate any potential air emissions for the desorption equipment and portable electric generators must also be obtained. All of the required operations of this remediation are routinely done at other remediation sites and should not be considered to be stumbling blocks. This remediation should be possible to complete in less than one year.

\section{$\underline{\operatorname{Cost}}$}

Alternative 1 is the lowest cost alternative as there are no costs involved with no action. Alternative 2 is estimated to have a present value of $\$ 10,346$. Alternative 3 has an estimated present value of $\$ 235,620$. Alternative 5 has a present value of $\$ 1,034,000$. Alternative 4 has a present value cost of $\$ 1,502,000$. 
D-Area Burning/Rubble Pits (431-D and 431-1D) Corrective Measures Study/Focused Feasibility Study (U) Savannah River Site

State Acceptance

Alternatives 4 and 5 would likely meet with the State's acceptance since these remediation methods would permanently reduce the risk to $1 \times 10^{-6}$ or less and allow unrestricted future land use of the area.

Alternative 2 would likely be acceptable to the State, if they agree that institutional controls can sufficiently protect human health at this site.

Alternative 3 would also likely be accepted by the State because the risks shown in this area do not pose a significant and complex site problem. There is a lack of principal threat source material within these pits and the residual contamination is spread out over a large area. The four foot soil cover would reduce the risk to $1 \mathrm{x}$ $10^{-6}$ for future residents. Alternative 1 would likely not be acceptable to the State. The ARAR for PCBs is not met.

\section{Community Acceptance}

The community would likely prefer alternative 2 . The CAB has recommended that this area be retained for future industrial land use only. This alternative is the lowest cost alternative that meets the ARARs and reduces the risk to $1 \times 10^{-6}$.

Alternative 3 may also be acceptable to the community if a low cost method is desired to return this land to residential use. Cover and control technologies have been used at other SRS waste sites with good public acceptance. It is, however, unlikely that the $\mathrm{CAB}$ would like to see this land made available for residential use.

The community would likely accept alternatives 4 and 5 as they would allow unrestricted future use of this land. Recent discussions at $\mathrm{CAB}$ meetings have indicated that this site is considered to be a minimal risk site and does not warrant significant spending to achieve a relatively small decrease in the risk posed by the site.

Alternative 1 would not likely be acceptable to the community. Some risk would exist to future residents if the land is opened for unrestricted future use.

\subsubsection{Summary of the Comparative Analysis of the Alternatives}

Table 3-1 is a summary of the costs of the five alternatives. Table 3-2 is a summary of the comparative analysis of the alternatives.

Table 3-1 : Summary of the Costs of the Alternatives

\begin{tabular}{|l|c|}
\hline \multicolumn{1}{|c|}{ Alternative } & Present Value \\
\hline 1 - No Action & $\$ 0$ \\
\hline 2 - Institutional Controls & $\$ 10,346$ \\
\hline 3 - Native Soil Cover (4') & $\$ 235,620$ \\
\hline 4 - Thermal Desorption/Incineration & $\$ 1,502,000$ \\
\hline 5 - Offsite Soil Disposal & $\$ 1,084,000$ \\
\hline
\end{tabular}




\begin{tabular}{|c|c|c|c|c|c|}
\hline Criterion & $\begin{array}{l}\text { Alternative } 1 \text {. } \\
\text { No Action }\end{array}$ & $\begin{array}{l}\text { Alternative } 2 \text { - } \\
\text { Institutional } \\
\text { Controls }\end{array}$ & $\begin{array}{l}\text { Alternative } 3 \text {. } \\
\text { Native Soil Cover } \\
\left(4^{\prime}\right)\end{array}$ & $\begin{array}{l}\text { Alternative } 4 \text { - } \\
\text { Thermal } \\
\text { Desorption/ } \\
\text { Incineration }\end{array}$ & $\begin{array}{l}\text { Alternative } 5 \text { - } \\
\text { Offsite Soil } \\
\text { Disposal }\end{array}$ \\
\hline \multicolumn{6}{|l|}{ Overall Protectiveness } \\
\hline Human Health & $\begin{array}{l}\text { Human health is } \\
\text { protected to a } 1 \times \\
10^{-5} \text { risk level. }\end{array}$ & $\begin{array}{l}\text { Human health is } \\
\text { protected. Deed } \\
\text { restrictions prohibit } \\
\text { use of the land for } \\
\text { residential use. }\end{array}$ & $\begin{array}{l}\text { Human health is } \\
\text { protected to } \\
1 \times 10^{-6} \text { level. }\end{array}$ & $\begin{array}{l}\text { Human health is } \\
\text { protected. }\end{array}$ & $\begin{array}{l}\text { Human health is } \\
\text { protected. }\end{array}$ \\
\hline Environment & Protective. & Protective. & Protective. & Protective. & Protective. \\
\hline \multicolumn{6}{|l|}{ Compliance with ARARs } \\
\hline Chemical-specific & $\begin{array}{l}\text { To-Be-Considered } \\
\text { guidance for PCBs } \\
\text { in soil in the top } \\
\text { four foot layer is } 1 \\
\text { mg/kg for } \\
\text { residential land use } \\
\text { and } 10 \mathrm{mg} / \mathrm{kg} \text { for } \\
\text { industrial land use. } \\
\text { This alternative } \\
\text { does not meet the } \\
\text { residential ARAR. }\end{array}$ & $\begin{array}{l}\text { To-Be-Considered } \\
\text { guidance for PCBs } \\
\text { in soil in the top } \\
\text { four foot layer is } 1 \\
\mathrm{mg} / \mathrm{kg} \text { for } \\
\text { residential land use } \\
\text { and } 10 \mathrm{mg} / \mathrm{kg} \text { for } \\
\text { industrial land use. } \\
\text { This alternative } \\
\text { meets the industrial } \\
\text { ARAR. }\end{array}$ & $\begin{array}{l}\text { To-Be-Considered } \\
\text { guidance for PCBs } \\
\text { in soil in the top } \\
\text { four foot layer is } 1 \\
\mathrm{mg} / \mathrm{kg} \text { for } \\
\text { residential land use } \\
\text { and } 10 \mathrm{mg} / \mathrm{kg} \text { for } \\
\text { industrial land use. } \\
\text { This alternative } \\
\text { meets the } \\
\text { residential ARAR. }\end{array}$ & $\begin{array}{l}\text { To-Be-Considered } \\
\text { guidance for PCBs } \\
\text { in soil in the top } \\
\text { four foot layer is } 1 \\
\mathrm{mg} / \mathrm{kg} \text { for } \\
\text { residential land use } \\
\text { and } 10 \mathrm{mg} / \mathrm{kg} \text { for } \\
\text { inclustrial land use. } \\
\text { This alternative } \\
\text { meets the industrial } \\
\text { ARAR. }\end{array}$ & $\begin{array}{l}\text { To-Be-Considered } \\
\text { guidance for } P C B s \\
\text { in soil in the top } \\
\text { four foot layer is } 1 \\
\mathrm{mg} / \mathrm{kg} \text { for } \\
\text { residential land use } \\
\text { and } 10 \mathrm{mg} / \mathrm{kg} \text { for } \\
\text { industrial land use. } \\
\text { This alternative } \\
\text { meets the industrial } \\
\text { ARAR. }\end{array}$ \\
\hline Location-specific & None. & None. & None. & None. & None. \\
\hline Action-specific & None. & None. & None. & $\begin{array}{l}\text { Will require } \\
\text { NESHAPS air } \\
\text { permit. }\end{array}$ & None. \\
\hline \multicolumn{6}{|c|}{ Long-Term Effectiveness And Permanence } \\
\hline Magnitude of residual risks & $\begin{array}{l}\text { All residual risk } \\
\text { remains. }\end{array}$ & $\begin{array}{l}\text { Residual risk } \\
\text { remains. Risks are } \\
1 \times 10^{-6} \text { or less if } \\
\text { land is retained for } \\
\text { industrial use only. }\end{array}$ & $\begin{array}{l}\text { Residual risk } \\
\text { remains. The risks } \\
\text { are } 1 \times 10^{-6} \text { or less } \\
\text { while the cover is } \\
\text { in place. }\end{array}$ & $\begin{array}{l}\text { Residual risk is } \\
\text { removed. }\end{array}$ & $\begin{array}{l}\text { Residual risk is } \\
\text { removed. }\end{array}$ \\
\hline Adequacy of controls & Inadequate. & $\begin{array}{l}\text { Adequate if deed } \\
\text { restrictions are } \\
\text { enforced. }\end{array}$ & $\begin{array}{l}\text { Adequate if the } \\
\text { cover remains } \\
\text { intact. }\end{array}$ & $\begin{array}{l}\text { Totally reliable. } \\
\text { Risk is removed. }\end{array}$ & $\begin{array}{l}\text { Totally reliable. } \\
\text { Risk is removed. }\end{array}$ \\
\hline
\end{tabular}




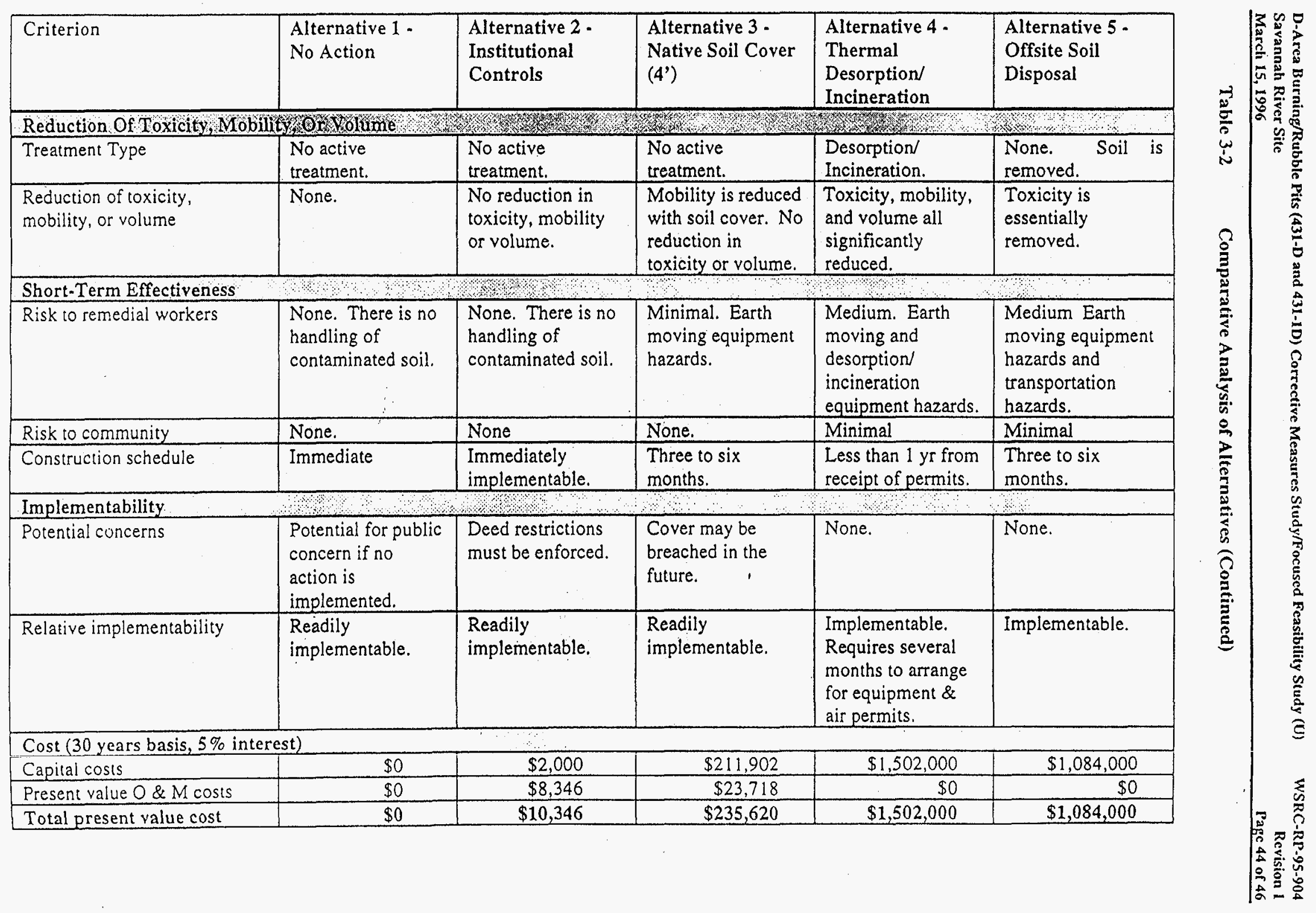


D-Area Burning/Rubble Pits (431-D and 431-1D) Corrective Measures Study/Focused Fcasibility Study (U) Savannah River Site

March 15, 1996

Table 3-2
WSRC-RP.95.904

Revision 1

Page 45 of 46

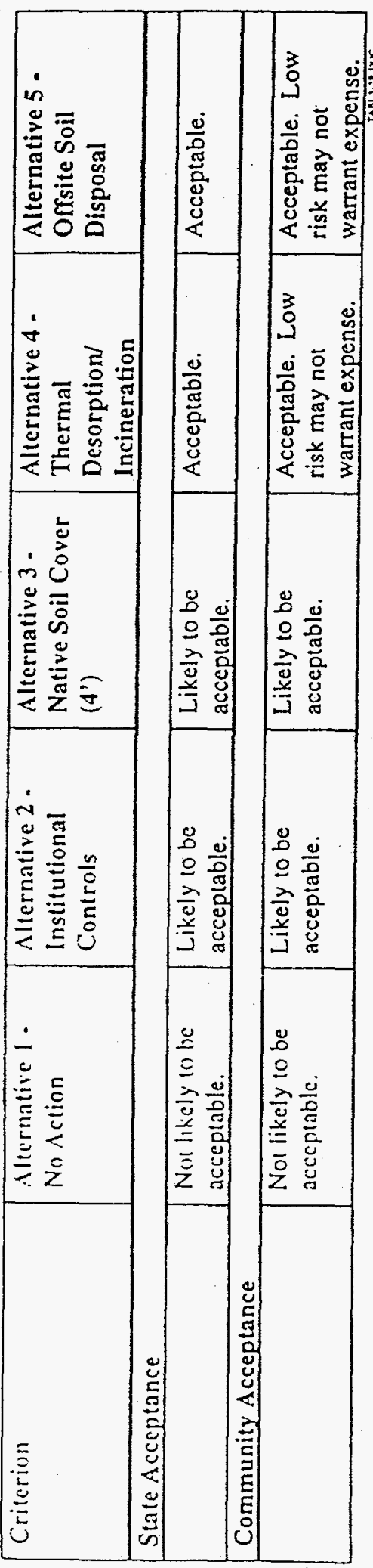


Crane, J. L., Memo to T. M. Treger: "Principles of Agreement for Performing Future Baseline Risk Assessment for the Savannah River Site (2X Mean Background), 8/94.

EPA, 1988. (U. S. Environmental Protection Agency). Guidance for Conducting Remedial Investigations and Feasibility Studies Under CERCLA. EPA/540/G-89/004, OSWER Directive 9355.3-01, Office of Emergency and Remedial Response, USEPA, Washington, DC, October, 1988.

EPA, 1990a. 40 CFR 264, Corrective Action for SWMUs at Hazardous Waste Management Facilities, Proposed Rule, Appendix A. - Examples of Concentrations Meeting Criteria for Actions Levels, 8/90.

EPA, 1990b. (U. S. Environmental Protection Agency). A Guide on Remedial Actions at Superfund Sites with $P C B$ Contamination. Office of Emergency and Remedial Response. Directive 9355.4-01 FS. August, 1990.

EPA, 1994a. Estimating Exposure to Dioxin-Like Compounds (Draft), 6/94.

EPA. 1994b. EPA Region III Risk-based Concentration Table, Fourth Quarter 1994. United States Environmental Protection Agency Region III. Philadelphia, PA, November 8, 1994.

EPA. 1994c. Vendor Information System for Innovative Treatment Technologies (VISITT). United States Environmental Protection Agency, Cincinnati, $\mathrm{OH}$.

Freeman. H. M. Standard Handbook of Hazardous Waste Treatment and Disposal. McGraw-Hill Book Company. New York, 1989.

NRC. 1989. Recommended Dietan Allowances, 10th Edition. National Research Council, National Academy Press. Washington. DC.

Tavlor. B. K. ct. al.. 1993. FYI993 SRS Waste Cost Analysis (U). WSRC-RP-93-942, Westinghouse Savannah River Company. Aiken. SC. July 31, 1993.

WSRC. 1995a. Baseline Risk Assessment for the D-Area Burning/Rubble. Pits (U). WSRC-TR-94-708, Rev. 1, Westinghouse Savannah River Company. Aiken. SC. May, 1995.

USRC. 1995b. RFI/RI Report for D-Area Burning/Rubble Pits (43I-D and 43I-ID) (U). WSRC-RP-94-707, Rer 1. Westunghouse Savannah River Company. Aiken. SC. May 1995.

WSRC. 1996. F-Area Burning/Rubble Pits (231-F. 23/-IF. and 231-2F) Corrective Measures Siudy Fcasibilirn Study (U). WSRC-RP-95-660. Rev 1. Westinghouse Savannah River Company, Aiken. SC. 
D-Area Burning/Rubble Pits (431-D and 431-1D) Corrective Measures Study/Focused Feasibility Study (U) Savannah River Site

March 15, 1996

\section{APPENDRX A}

\section{Cost Estimates}

The cost estimates below were designed to be within +50 percent and -30 percent of the actual values. Present values for each of the alternatives were calculated using a 30 year remediation period and an annual interest rate of 5 percent.

Table A-1

Present Value of Alternative 1 - No Action

\begin{tabular}{|l|c|c|c|c|}
\hline \multicolumn{1}{|c|}{ Activity } & Cost & Years & PV Factor & Present Value \\
\hline No costs associated with No Action. & $\$ 0$ & & & $\$ 0$ \\
\hline \hline Total Present Value & & & & $\$ 0$ \\
\hline
\end{tabular}

Table A-2

Present Value of Alternative 2 - Institutional Controls

\begin{tabular}{|l|c|c|c|c|}
\hline \multicolumn{1}{|c|}{ Activity } & Cost & Years & PV Factor & Present Value \\
\hline Deed restrictions (industrial use only) & $\$ 2,000$ & 1 & 1 & $\$ 2,000$ \\
\hline 5 Year ROD reviews & $\$ 3,000$ & $5 / 30$ & 2.782 & $\$ 8,346$ \\
\hline \hline Total Present Value & & & & $\$ 10,346$ \\
\hline
\end{tabular}

Table A-3 Present Value of Alternative 3 - Native Soil Cover (4')

\begin{tabular}{|l|c|c|c|c|}
\hline \multicolumn{1}{|c|}{ Activity } & Cost & Years & PV Factor & Present Value \\
\hline $\begin{array}{l}\text { Deed notifications, land survey, } \\
\text { groundwater use restrictions }\end{array}$ & $\$ 2,000$ & 1 & 1 & $\$ 2,000$ \\
\hline Preparation of an RD/RA work plan & $\$ 50,000$ & 1 & 1 & $\$ 50,000$ \\
\hline Native Soil Cover, 4 ft thick, feathered & $\$ 159,902$ & 1 & 1 & $\$ 159,902$ \\
\hline Maintenance & $\$ 1,000$ & 30 & 15.37 & $\$ 15,372$ \\
\hline 5 Year ROD reviews & $\$ 3,000$ & $5 / 30$ & 2.782 & $\$ 8,346$ \\
\hline \hline Total Present Value & & & & $\$ 235,620$ \\
\hline
\end{tabular}


D-Area Burning/Rubble Pits (431-D and 431-1D) Corrective Measures Study/Focused Feasibility Study (U) Savannah River Site

WSRC-RP-95-904 March 15,1996

Table A-4 Present Value of Alternative 4 - Thermal Desorption/Incineration

\begin{tabular}{|l|c|c|c|c|}
\hline \multicolumn{1}{|c|}{ Activity } & Cost & Years & PV Factor & Present Value \\
\hline Obtain air permit for incineration of PCBs & $\$ 150,000$ & 1 & 1 & $\$ 150,000$ \\
\hline Deed restrictions, groundwater use & $\$ 2,000$ & 1 & 1 & $\$ 2,000$ \\
\hline Preparation of an RD/RA work plan & $\$ 150,000$ & 1 & 1 & $\$ 150,000$ \\
\hline Thermal Desorption/Incineration (turnkey) & $\$ 1,200,000$ & 1 & 1 & $\$ 1,200,000$ \\
\hline \hline Total Present Value & & & & $\$ 1,502,000$ \\
\hline
\end{tabular}

Table A-5 Present Value of Alternative 5 - Offsite Soil Disposal

\begin{tabular}{|l|c|c|c|c|}
\hline \multicolumn{1}{|c|}{ Activity } & Cost & Years & PV Factor & Present Value \\
\hline Soil Excavation & $\$ 40,000$ & 1 & 1 & $\$ 40,000$ \\
\hline Transportation & $\$ 200,000$ & 1 & 1 & $\$ 200,000$ \\
\hline Deed restrictions, groundwater use & $\$ 2,000$ & 1 & 1 & $\$ 2,000$ \\
\hline Preparation of an RD/RA work plan & $\$ 150,000$ & 1 & 1 & $\$ 150,000$ \\
\hline Disposal costs & $\$ 652,000$ & 1 & 1 & $\$ 652,000$ \\
\hline Backfill pits, revegetate & $\$ 40,000$ & 1 & 1 & $\$ 40,000$ \\
\hline \hline Total Present Value & & & & $\$ 1,084,000$ \\
\hline
\end{tabular}


APPENDIX B

\section{Calculation of Soil Remedial Action Objectives}

Preliminary Remedial Action Objectives (RAOs) for the soil contaminants were developed from the groundwater Preliminary Remediation Goals (PRGs) that were calculated in the Baseline Risk Assessment (BRA) and from comparisons to ARARs. RAOs were only developed for the soil contaminants which significantly contributed to the risk calculated for a pathway which was equal to or exceeded $1 \times 10^{-4}$ or a hazard index (HI) of greater than 1. If the modeled groundwater concentration was predicted to exceed a primary MCL, an RAO was calculated for that contaminant, based on the MCL. Table B-1 lists the parameters used to calculate the RAOs. The column labeled "Soil RME" includes the soil concentrations used in the BRA as input into the soil to groundwater model. The column labeled "Groundwater" lists the groundwater concentrations as predicted by the model. The ratio of soil to groundwater is used to determine acceptable soil concentrations when multiplied by the appropriate groundwater criteria (e.g., PRG or MCL). All PRGs are based on a risk of 1 $x 10^{-6}$ or an $\mathrm{HI}$ of 0.1 . In the cases where both a PRG and an MCL are listed for a single contaminant, the MCL value was used. Soil RAOs are in the same units as the soil RME values.

\section{Table B-1 Calculation of Soil Remedial Action Objectives}

\begin{tabular}{|c|c|c|c|c|c|c|c|}
\hline Contaminant & Units & Soil RME & $\begin{array}{c}\text { Groundwate } \\
\mathbf{r} \\
(\mu g / L)\end{array}$ & $\begin{array}{c}\text { Ratio of Soil } \\
\text { to Ground water }\end{array}$ & $\begin{array}{c}\text { Groundwater } \\
\left.\text { (PRG }-1 \times 10^{-6}\right)\end{array}$ & $\begin{array}{l}\text { Groundwater } \\
\text { (PRG - HI =0.1) }\end{array}$ & Soil RAO \\
\hline 1,1,2-Trichloroethane & $\mu \mathrm{g} / \mathrm{kg}$ & 3.74 & 8.60 & $4.35 \times 10^{-1}$ & 1.20 & $\overline{M C L}=5.0$ & 2.17 \\
\hline 1,2-Dichloroethane & $\mu g / \mathrm{kg}$ & 3.07 & $1.15 \times 10^{+1}$ & $2.67 \times 10^{-1}$ & $7.30 \times 10^{-1}$ & $\mathrm{MCL}=5.0$ & 1.33 \\
\hline 2-Methylnaphthalene & $\mu g / \mathrm{kg}$ & $1.66 \times 10^{+3}$ & $1.22 \times 10^{+2}$ & $1.36 \times 10^{+1}$ & & $2.70 \times 10^{+1}$ & $3.67 \times 10^{+2}$ \\
\hline Acenaphthene & $\mu \mathrm{g} / \mathrm{kg}$ & $9.13 \times 10^{+2}$ & $1.07 \times 10^{+2}$ & 8.53 & & $4.10 \times 10^{+1}$ & $3.50 \times 10^{+2}$ \\
\hline Acetone & $\mu \mathrm{g} / \mathrm{kg}$ & $5.80 \times 10^{+3}$ & $1.71 \times 10^{+4}$ & $3.39 \times 10^{-1}$ & & $1.09 \times 10^{+2}$ & $1.39 \times 10^{+1}$ \\
\hline Arsenic & $\mathrm{mg} / \mathrm{kg}$ & 3.10 & $5.19 \times 10^{-1}$ & 5.97 & $3.80 \times 10^{-2}$ & & $2.27 \times 10^{-1}$ \\
\hline Benzene & $\mu \mathrm{g} / \mathrm{kg}$ & 3.03 & 6.27 & $4.83 \times 10^{-1}$ & 2.20 & $\mathrm{MCL}=5.0$ & 2.42 \\
\hline Benzo(a)anthracene & $\mu \mathrm{g} / \mathrm{kg}$ & $2.34 \times 10^{+3}$ & $9.48 \times 10^{-1}$ & $2.46 \times 10^{+3}$ & $9.20 \times 10^{-3}$ & & $2.27 \times 10^{+1}$ \\
\hline Benzo(a)pyrene & $\mu \mathrm{g} / \mathrm{kg}$ & $1.91 \times 10^{+3}$ & $1.94 \times 10^{-1}$ & $9.83 \times 10^{+3}$ & $9.20 \times 10^{-3}$ & & $9.04 \times 10^{+1}$ \\
\hline Benzo(b)fluoranthene & $\mu \mathrm{g} / \mathrm{kg}$ & $2.50 \times 10^{+3}$ & 2.55 & $9.82 \times 10^{+2}$ & $9.20 \times 10^{-3}$ & & 9.03 \\
\hline Benzo(k)fluoranthene & $\mu \mathrm{g} / \mathrm{kg}$ & $1.03 \times 10^{+3}$ & 1.04 & $9.87 \times 10^{+2}$ & $9.20 \times 10^{-3}$ & & 9.08 \\
\hline Butylbenzyl phthalate & $\mu g / \mathrm{kg}$ & $5.46 \times 10^{+2}$ & $5.69 \times 10^{42}$ & $9.59 \times 10^{-1}$ & & $2.20 \times 10^{+2}$ & $2.11 \times 10^{+2}$ \\
\hline Dibenz(a,h)anthracene & $\mu \mathrm{g} / \mathrm{kg}$ & $1.58 \times 10^{+3}$ & $2.68 \times 10^{-1}$ & $5.89 \times 10^{43}$ & $9.20 \times 10^{-3}$ & & $5.42 \times 10^{+1}$ \\
\hline Dibenzofuran & $\mu \mathrm{g} / \mathrm{kg}$ & $8.41 \times 10^{+2}$ & $5.66 \times 10^{+1}$ & $1.49 \times 10^{+1}$ & & 4.00 & $5.95 \times 10^{+1}$ \\
\hline $\begin{array}{l}\text { Dichloromethane } \\
\text { (methylene chloride) }\end{array}$ & $\mu g / \mathrm{kg}$ & $1.17 \times 10^{+1}$ & $3.05 \times 10^{+1}$ & $3.84 \times 10^{-1}$ & $1.50 \times 10^{41}$ & $\mathrm{MCL}=5.0$ & 1.92 \\
\hline Fluoranthene & $\mu \mathrm{g} / \mathrm{kg}$ & $3.85 \times 10^{+3}$ & $5.64 \times 10^{41}$ & $6.82 \times 10^{+1}$ & & $4.40 \times 10^{+1}$ & $3.00 \times 10^{+3}$ \\
\hline HpCDD & $\mu \mathrm{g} / \mathrm{kg}$ & $2.80 \times 10^{-1}$ & $4.75 \times 10^{-5}$ & $5.89 \times 10^{+3}$ & $1.20 \times 10^{-6}$ & & $7.07 \times 10^{-3}$ \\
\hline Indeno(1,2,3-cd)pyrene & $\mu \mathrm{g} / \mathrm{kg}$ & $1.20 \times 10^{+3}$ & $4.20 \times 10^{-1}$ & $2.85 \times 10^{+3}$ & $9.20 \times 10^{-3}$ & & $2.63 \times 10^{41}$ \\
\hline Naphthalene & $\mu \mathrm{g} / \mathrm{kg}$ & $9.28 \times 10^{42}$ & $7.05 \times 10^{+2}$ & 1.32 & & $3.60 \times 10^{+1}$ & $4.74 \times 10^{+1}$ \\
\hline$\overline{\mathrm{OCDD}}$ & $\mu \mathrm{g} / \mathrm{kg}$ & $1.35 \times 10^{41}$ & $7.56 \times 10^{-4}$ & $1.79 \times 10^{+4}$ & $1.20 \times 10^{-5}$ & & $2.14 \times 10^{-1}$ \\
\hline
\end{tabular}

Note: For PCBs the ARAR levels were used. 